Atmos. Chem. Phys., 18, 12817-12843, 2018

https://doi.org/10.5194/acp-18-12817-2018

(C) Author(s) 2018. This work is distributed under

the Creative Commons Attribution 4.0 License.

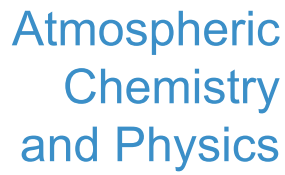

(c) (P)

\title{
Black and brown carbon over central Amazonia: long-term aerosol measurements at the ATTO site
}

\author{
Jorge Saturno $^{1, a}$, Bruna A. Holanda ${ }^{1}$, Christopher Pöhlker ${ }^{1}$, Florian Ditas ${ }^{1}$, Qiaoqiao Wang ${ }^{1,2}$, \\ Daniel Moran-Zuloaga ${ }^{1}$, Joel Brito ${ }^{3,4}$, Samara Carbone ${ }^{3,5}$, Yafang Cheng ${ }^{1}$, Xuguang Chi $^{6}$, Jeannine Ditas ${ }^{1,2}$, \\ Thorsten Hoffmann $^{7}$, Isabella Hrabe de Angelis ${ }^{1}$, Tobias Könemann ${ }^{1}$, Jošt V. Lavrič ${ }^{8}$, Nan Ma ${ }^{1,2}$, Jing Ming ${ }^{1}$, \\ Hauke Paulsen ${ }^{9}$, Mira L. Pöhlker ${ }^{1}$, Luciana V. Rizzo ${ }^{10}$, Patrick Schlag ${ }^{3}$, Hang Su ${ }^{1}$, David Walter ${ }^{1}$, Stefan Wolff ${ }^{1}$, \\ Yuxuan Zhang ${ }^{1}$, Paulo Artaxo ${ }^{3}$, Ulrich Pöschl ${ }^{1}$, and Meinrat O. Andreae ${ }^{1,11}$ \\ ${ }^{1}$ Multiphase Chemistry \& Biogeochemistry Departments, Max Planck Institute for Chemistry, 55128 Mainz, Germany \\ ${ }^{2}$ Jinan University Institute for Environmental and Climate Research, Guangzhou, 510630, China \\ ${ }^{3}$ Institute of Physics, University of São Paulo, São Paulo, 05508-900, Brazil \\ ${ }^{4}$ Laboratory for Meteorological Physics, Université Clermont Auvergne, 63000 Clermont-Ferrand, France \\ ${ }^{5}$ Institute of Agrarian Sciences, Federal University of Uberlândia, Uberlândia, Minas Gerais, 38408-100, Brazil \\ ${ }^{6}$ Institute for Climate and Global Change Research \& School of Atmospheric Sciences, Nanjing University, \\ Nanjing, 210093, China \\ ${ }^{7}$ Department of Chemistry, Johannes Gutenberg University, 55128 Mainz, Germany \\ ${ }^{8}$ Biogeochemical Systems \& Biogeochemical Processes Departments, Max Planck Institute for Biogeochemistry, \\ 07701 Jena, Germany \\ ${ }^{9}$ Institute of General Botany, Johannes Gutenberg University, 55128 Mainz, Germany \\ ${ }^{10}$ Departamento de Ciencias Ambientais, Universidade Federal de Sao Paulo, Diadema, SP, Brazil \\ ${ }^{11}$ Scripps Institution of Oceanography, University of California San Diego, La Jolla, CA 92098, USA \\ ${ }^{a}$ now at: Physikalisch-Technische Bundesanstalt, Bundesallee 100, 38116 Braunschweig, Germany
}

Correspondence: Jorge Saturno (j.saturno@mpic.de) and Christopher Pöhlker (c.pohlker@mpic.de)

Received: 24 November 2017 - Discussion started: 12 December 2017

Revised: 2 June 2018 - Accepted: 10 August 2018 - Published: 6 September 2018

\begin{abstract}
The Amazon rainforest is a sensitive ecosystem experiencing the combined pressures of progressing deforestation and climate change. Its atmospheric conditions oscillate between biogenic and biomass burning (BB) dominated states. The Amazon further represents one of the few remaining continental places where the atmosphere approaches pristine conditions during occasional wet season episodes. The Amazon Tall Tower Observatory (ATTO) has been established in central Amazonia to investigate the complex interactions between the rainforest ecosystem and the atmosphere. Physical and chemical aerosol properties have been analyzed continuously since 2012 . This paper provides an in-depth analysis of the aerosol's optical properties at ATTO based on data from 2012 to 2017. The following key results have been obtained.
\end{abstract}

- The aerosol scattering and absorption coefficients at $637 \mathrm{~nm}, \sigma_{\mathrm{sp}, 637}$ and $\sigma_{\mathrm{ap}, 637}$, show a pronounced seasonality with lowest values in the clean wet season $\left(\right.$ mean $\pm \mathrm{SD}: \sigma_{\mathrm{sp}, 637}=7.5 \pm 9.3 \mathrm{M} \mathrm{m}^{-1} ; \sigma_{\mathrm{ap}, 637}=$ $\left.0.68 \pm 0.91 \mathrm{M} \mathrm{m}^{-1}\right)$ and highest values in the BBpolluted dry season $\left(\sigma_{\mathrm{sp}, 637}=33 \pm 25 \mathrm{M} \mathrm{m}^{-1} ; \sigma_{\mathrm{ap}, 637}=\right.$ $\left.4.0 \pm 2.2 \mathrm{M} \mathrm{m}^{-1}\right)$. The single scattering albedo at $637 \mathrm{~nm}, \omega_{0}$, is lowest during the dry season $\left(\omega_{0}=\right.$ $0.87 \pm 0.03)$ and highest during the wet season $\left(\omega_{0}=\right.$ $0.93 \pm 0.04)$.

- The retrieved BC mass absorption cross sections, $\alpha_{\mathrm{abs}}$, are substantially higher than values widely used in the literature (i.e., $6.6 \mathrm{~m}^{2} \mathrm{~g}^{-1}$ at $637 \mathrm{~nm}$ wavelength), likely related to thick organic or inorganic coatings on the BC cores. Wet season values of $\alpha_{\mathrm{abs}}=11.4 \pm$ 
$1.2 \mathrm{~m}^{2} \mathrm{~g}^{-1}(637 \mathrm{~nm})$ and dry season values of $\alpha_{\mathrm{abs}}=$ $12.3 \pm 1.3 \mathrm{~m}^{2} \mathrm{~g}^{-1}(637 \mathrm{~nm})$ were obtained.

- The BB aerosol during the dry season is a mixture of rather fresh smoke from local fires, somewhat aged smoke from regional fires, and strongly aged smoke from African fires. The African influence appears to be substantial, with its maximum from August to October. The interplay of African vs. South American BB emissions determines the aerosol optical properties (e.g., the fractions of black vs. brown carbon, $\mathrm{BC}$ vs. $\mathrm{BrC}$ ).

- By analyzing the diel cycles, it was found that particles from elevated aerosol-rich layers are mixed down to the canopy level in the early morning and particle number concentrations decrease towards the end of the

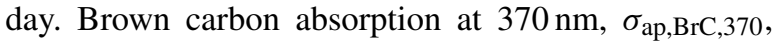
was found to decrease earlier in the day, likely due to photo-oxidative processes.

- BC-to-CO enhancement ratios, $\mathrm{ER}_{\mathrm{BC}}$, reflect the variability of burnt fuels, combustion phases, and atmospheric removal processes. A wide range of $\mathrm{ER}_{\mathrm{BC}}$ between 4 and $15 \mathrm{ng} \mathrm{m}^{-3} \mathrm{ppb}^{-1}$ was observed with higher values during the dry season, corresponding to the lowest $\omega_{0}$ levels (0.86-0.93).

- The influence of the 2009/2010 and 2015/2016 El Niño periods and the associated increased fire activity on aerosol optical properties was analyzed by means of 9year $\sigma_{\text {sp }}$ and $\sigma_{\text {ap }}$ time series (combination of ATTO and ZF2 data). Significant El Niño-related enhancements were observed: in the dry season, $\sigma_{\mathrm{sp}, 637}$ increased from $24 \pm 18$ to $48 \pm 33 \mathrm{M} \mathrm{m}^{-1}$ and $\sigma_{\mathrm{ap}, 637}$ from $3.8 \pm 2.8$ to $5.3 \pm 2.5 \mathrm{M} \mathrm{m}^{-1}$.

- The absorption Ångström exponent, $\stackrel{\circ}{a b s}_{\text {, }}$ representing the aerosol absorption wavelength dependence, was mostly $<1.0$ with episodic increases upon smoke advection. A parameterization of $\stackrel{a}{a}_{\text {abs }}$ as a function of the BCto-OA mass ratio for Amazonian aerosol ambient measurements is presented. The brown carbon $(\mathrm{BrC})$ contribution to $\sigma_{\text {ap }}$ at $370 \mathrm{~nm}$ was obtained by calculating the theoretical BC $\stackrel{\circ}{a}_{\text {abs }}$, resulting in $\mathrm{BrC}$ contributions of $17 \%-29 \%$ (25th and 75 th percentiles) to $\sigma_{\text {ap }} 370$ for the entire measurement period. The $\mathrm{BrC}$ contribution increased to $27 \%-47 \%$ during fire events under El Niñorelated drought conditions from September to November 2015 .

The results presented here may serve as a basis to understand Amazonian atmospheric aerosols in terms of their interactions with solar radiation and the physical and chemicalaging processes that they undergo during transport. Additionally, the analyzed aerosol properties during the last two El Niño periods in 2009/2010 and 2015/2016 offer insights that could help to assess the climate change-related potential for forest-dieback feedbacks under warmer and drier conditions.

\section{Introduction}

Atmospheric aerosol particles affect the Earth's climate through different mechanisms. Direct mechanisms include the aerosol particle interactions with radiation by scattering and absorption. The balance between scattering and absorption can lead to warming or cooling of the atmosphere (IPCC, 2013). Moreover, indirect mechanisms, like aerosol-cloud interactions during cloud formation and cloud microphysical modifications, are accompanied by high uncertainties, especially due to the lack of knowledge on pre-industrial levels of cloud condensation nuclei (CCN) (Carslaw et al., 2013) and aerosol spatial distribution in the atmosphere (Andreae, 2007).

Continuous aerosol measurements at remote continental locations are crucial to understand atmospheric conditions prior to industrialization and reduce the uncertainties in climate models (Seinfeld et al., 2016). The Amazon Basin is one of the few continental areas in the world where the atmosphere approximates pristine conditions during some periods of the year (Andreae et al., 2015; M. L. Pöhlker et al., 2018). However, anthropogenic pollution is rather persistent and, thus, reaches almost every place on the planet (Andreae, 2007; Chi et al., 2013; Hamilton et al., 2014). The Amazon rainforest has been impacted substantially by intensified agriculture and the associated deforestation and infrastructural development in the last 50 years (Artaxo et al., 2013; Davidson et al., 2012). Given these circumstances, only when air masses travel over clean marine areas and rain-related scavenging is significant do the observations approach near-pristine to pristine levels (Andreae et al., 2012, 2015; M. L. Pöhlker et al., 2018).

Biogenic primary and secondary organic aerosol particles over the Amazon rainforest are ubiquitous throughout the year (Martin et al., 2010b). During the dry season (AugustNovember), when fires are frequent in the forest and its peripheries, the background biogenic aerosol is overwhelmed by BB smoke (Andreae et al., 1988; Artaxo et al., 2002; Fuzzi et al., 2007; Guyon et al., 2003a; Roberts et al., 2003). Despite the rare occurrence of natural tropical forest fires (Cochrane, 2003; Nepstad et al., 2008), most of the fire episodes in the Amazon rainforest peripheries occur due to human activity, including land use change, brush clearing for agricultural activities, burning of agricultural waste (Andreae, 1991; Crutzen and Andreae, 1990), and cooperative burning of savannas by indigenous communities, which is done to prevent larger wildfires (Bilbao et al., 2010). Starting in August, the dry season is characterized by aerosol number concentrations of $1000-3000 \mathrm{~cm}^{-3}$ (Andreae et al., 2015). Another characteristic of the dry season is the occurrence of abundant black carbon (BC) in the atmosphere. This type of aerosol particles is primarily emitted by flaming and smoldering fires together with large amounts of organic aerosols (OA) (Andreae and Merlet, 2001) and is considered an important short-lived climate forcing agent (Andreae, 2001; 
Bond et al., 2004, 2013). The light absorbing fraction of OA, which is co-emitted with $\mathrm{BC}$, is called brown carbon $(\mathrm{BrC})$ (Andreae and Gelencsér, 2006). The $\mathrm{BC}+\mathrm{BrC}$ aerosol fraction is commonly defined as light-absorbing carbonaceous (LAC) matter (Petzold et al., 2013). A list of frequently used acronyms and symbols can be found in Table A1.

During combustion, aerosol particles are co-emitted with carbon monoxide $(\mathrm{CO})$. The ratio between aerosol mass or number concentrations and $\mathrm{CO}$ has been used to trace the origin and age of air masses (Guyon et al., 2005; Janhäll et al., 2010). Enhancement ratios $\left(\mathrm{ER}_{\mathrm{BC}}\right)$ for open biomass burning measured for boreal forest smoldering fires have an average $\mathrm{ER}_{\mathrm{BC}}$ of $1.7 \mathrm{ng} \mathrm{m}^{-3} \mathrm{ppb}^{-1}$ (Kondo et al., 2011). In contrast, agricultural fires exhibit higher $\mathrm{ER}_{\mathrm{BC}}$ compared to forest fires, with reported values varying between 2.2 and $30 \mathrm{ng} \mathrm{m}^{-3} \mathrm{ppb}^{-1}$ (Mikhailov et al., 2017, and references therein).

Biomass burning plumes are usually dominated by accumulation mode aerosol particles, which are efficient to scatter radiation in the UV-visible range and are also rich in $\mathrm{BC}$. In the absence of BB aerosol particles, the biological coarse mode particles become dominant in terms of mass and the aerosol optical properties are affected (Moran-Zuloaga et al., 2018). Therefore, clear seasonal trends in scattering and absorption have been observed by long-term measurements in the Amazon region (Rizzo et al., 2013).

The light absorption of $\mathrm{BC}$ has a wavelength dependence that depends on the $\mathrm{BC}$ mixing state, its size distribution, and the composition of co-emitted particles (Andreae and Gelencsér, 2006; Kirchstetter et al., 2004; Lack et al., 2013; Schuster et al., 2016). The wavelength dependence is described by the absorption Ångström exponent $\left(\stackrel{\circ}{a}_{\text {abs }}\right)$ (Ångström, 1929). It varies from low values $\left(\stackrel{\circ}{a}_{\text {abs }}=\right.$ $1.0 \pm 0.1$, weak spectral dependence), usually associated with fossil fuel emitted BC (Bond and Bergstrom, 2006), up to high values ( $\stackrel{\circ}{a b s}_{a}=6-7$, strong spectral dependence) for organic-rich aerosol, e.g., humic-like substances (Hoffer et al., 2006). Measurements at an Amazonian forest site during the dry season resulted in $\stackrel{\circ}{a b s}_{\text {abs }}$ average values below 1.0 for absorption coefficients lower than $15 \mathrm{M} \mathrm{m}^{-1}$ at $450 \mathrm{~nm}$ (Rizzo et al., 2011). For BB aerosol particles, the $\stackrel{\leftrightarrow}{a}_{\text {abs }}$ is usually higher than 1.0. However, it depends on the burning conditions, the BC-to-OA ratio (Saleh et al., 2014), and the BC$\mathrm{BrC}$ size distributions and morphologies (Kirchstetter et al., 2004; Womack et al., 2017). Several studies have used the absorption spectral dependence to apportion the fossil fuel and BB contributions to total absorption (Favez et al., 2010; Massabò et al., 2015; Sandradewi et al., 2008). However, the $\stackrel{\circ}{a}_{\text {abs }}$ values do not always reflect the combustion type, and using it as a source apportionment parameter can lead to erroneous results (Garg et al., 2016; Lack and Langridge, 2013; Lewis et al., 2008; Wang et al., 2016b). Several studies assume a BC $\stackrel{\circ}{a b s}_{\text {ab }}$ of 1.0, but models show that pure BC could exhibit a broader range of $\stackrel{\circ}{a b s}_{\text {ab }}$ values (Moosmüller et al., 2011). In order to retrieve the ambient BC wavelength dependence, Wang et al. (2016b) proposed the use of the wavelength dependence of $\stackrel{\circ}{a}_{\text {abs }}$ instead of $\stackrel{a}{a}_{\text {abs }}$ itself. The socalled wavelength dependence of $\stackrel{\circ}{a b s}_{\text {abD }}$ (WD) is calculated as the difference of two wavelength pairs: one for short to long wavelengths (e.g., $440-870 \mathrm{~nm}$ ) and another for medium to long wavelengths (e.g., 675-880 nm).

Precise $\mathrm{BC}$ mass measurements are required to retrieve the correct relationship between absorptivity and BC mass, defined as the mass absorption cross section (MAC or $\alpha_{\mathrm{abs}}$ ). The BC mass concentration has traditionally been measured by using thermal or thermal-optical techniques (Cachier et al., 1989; Chow et al., 2007). However, these methods suffer from several biases, like organic carbon charring that increases the apparent BC concentration, especially when high organic fractions are present (Andreae and Gelencsér, 2006). More recently, laser-induced incandescence (LII) techniques have been introduced (Snelling et al., 2005). These techniques measure the volume-equivalent mass of refractory black carbon (rBC) that vaporizes at temperatures of 2800 $4000 \mathrm{~K}$. The MAC is used by atmospheric radiative transfer models to obtain absorption coefficients from mass concentration data. The MAC of BC varies between 4 and $11 \mathrm{~m}^{2} \mathrm{~g}^{-1}$ at $550 \mathrm{~nm}$, with an average of $6.5 \mathrm{~m}^{2} \mathrm{~g}^{-1}$ at $637 \mathrm{~nm}$ for fresh soot (Bond and Bergstrom, 2006). In case of condensation of non-BC material on the BC particles, the MAC can be enhanced due to the well-known "lensing effect" (Fuller et al., 1999). This commonly happens when BC is emitted by BB, since it is co-emitted with large amounts of organic vapors that can condense on BC particles (Saleh et al., 2014). In the central Amazon, black carbon particles have been shown to be coated by organic and inorganic matter (Pöhlker et al., 2014; Pöschl et al., 2010). It has been found that the coating mass significantly affects the absorption enhancement of $\mathrm{BC}$ particles, but no significant changes are caused by variations in the coating's oxygen-to-carbon ratio (Tasoglou et al., 2017). A wide range of MAC values can be found in the literature for different fire conditions (smoldering and flaming).

Commonly, the absorption properties of an aerosol population are reported as the single scattering albedo (SSA, $\left.\omega_{0}\right)$, which is defined as total scattering divided by total extinction (absorption + scattering). Therefore, a lower $\omega_{0}$ is associated with a stronger absorption. Tropical Amazonian forest fires have moderately high $\omega_{0}$ values $(0.93 \pm 0.02$ at $670 \mathrm{~nm})$, given the high amount of scattering aerosols which are coemitted with LAC, compared to African savanna fires that have lower $\omega_{0}$ values $(0.84 \pm 0.015$ at $670 \mathrm{~nm})$ (Reid et al., 2005). In the Amazon rainforest, long-term measurements by Rizzo et al. (2013) have found similar values for $\omega_{0}$ during the dry and wet seasons, $0.87 \pm 0.06$ and $0.86 \pm 0.09$, respectively. The low $\omega_{0}$ in the wet season is attributed to longrange transported aerosols that include mineral dust and aged BB aerosol particles. Aged BB aerosol is proven to have increased MAC, and therefore lower $\omega_{0}$ (Reid et al., 2005). Moreover, the biogenic part of the aerosol can contribute up to $35 \%$ of total light absorption (Guyon et al., 2004). 
When present in large amounts in the atmosphere, mineral dust can significantly absorb light, with a MAC of 0.02$0.1 \mathrm{~m}^{2} \mathrm{~g}^{-1}$ at $550 \mathrm{~nm}$ (Clarke and Charlson, 1985). It is mobilized from soils and suspended in the atmosphere by windstorms in areas like the Saharan desert in Africa. Dust aerosol particles in the atmosphere efficiently scatter visible radiation and are able to absorb infrared radiation (Andreae, 1996), having a $\stackrel{\circ}{a b s}_{\text {ab }} \gg 1.0$ (Caponi et al., 2017; Denjean et al., 2016). Mineral dust plumes travel over the Atlantic Ocean and are able to reach the American continent. Depending on the circulation patterns over the tropical Atlantic, the African dust plumes will be transported to South America or to the Caribbean Sea and central America (Prospero et al., 1981). The average transport time from emission to deposition in the Amazon Basin during winter is $\sim 10$ days (Gläser et al., 2015). Ground measurements of aerosol physical and chemical properties have confirmed that between January and April mineral dust plumes from Africa episodically dominate the aerosol load over large parts of the Amazon rainforest (Formenti et al., 2001; Guyon et al., 2004; MoranZuloaga et al., 2018; Talbot et al., 1990; Wang et al., 2016a). Moreover, the dust-enriched aerosol usually arrives together with BB aerosol emitted by fires in sub-Sahelian western Africa and also aerosol particles emitted by industrial activities in Morocco and the western Saharan coast (MoranZuloaga et al., 2018; Salvador et al., 2016). In spite of anthropogenic disturbance of soils in Africa that could enhance the flux of mineral dust to the atmosphere (Andreae, 1991), a decreasing trend in mineral dust emissions since the 1980s has been observed and is mainly caused by a reduction of surface winds in the Sahel region (Ridley et al., 2014).

This study provides a comprehensive and in-depth analysis of the aerosol optical properties in the Amazonian atmosphere. A continuous long-term data set (2012-2017) of different optical properties is provided. We particularly focus on the impact of $\mathrm{BB}$ emissions from long-range transport and from regional/local open fires during the dry season. By using data from another central Amazonian remote sampling site, we extend our time series back to 2008 and provide the longest data set on optical properties measured in the Amazon rainforest so far. By these means, we are able to study the perturbations caused by the El Niño-Southern Oscillation (ENSO), which has been reported to cause droughts in the Amazon Basin (see Fig. S1 in the Supplement), with increasing fire activity and forest degradation (Aragão et al., 2007; Cochrane, 2003; Davidson et al., 2012; Lewis et al., 2011).

\section{Materials and methods}

\subsection{Sampling site and measurement period}

Aerosol particles and trace gases have been measured at the Amazon Tall Tower Observatory (ATTO) site, located in the Uatumã Sustainable Development Reserve, Amazonas State, Brazil, in central Amazonia since 2011 (Andreae et al., 2015). The large-scale meteorological conditions of the site are determined by the seasonal migration of the intertropical convergence zone (ITCZ) (C. Pöhlker et al., 2018). From August to November, during the dry season, the ITCZ is located in the north of South America, and mostly Southern Hemisphere air masses reach the ATTO site, bringing BB emissions from deforestation hotspots in southeastern Brazil (i.e., the so-called arc of deforestation) as well as transcontinental emissions from southern Africa. During the wet season, from February to May, when the ITCZ shifts to southern latitudes, the air masses generally come from the Northern Hemisphere, following a path over the Atlantic Ocean from the African continent and then over mostly untouched forest areas upwind of the ATTO site. The transition seasons, dry to wet and wet to dry, occur in December-January and June-July, respectively.

At the ATTO site, systematic aerosol measurements were started in March 2012, being continuously extended and intensified since then. In the course of this process, the aerosol inlet system was modified and upgraded step-wise. A detailed list of the different inlet configurations and characteristics can be found in Table S1. On 4 May 2014, a PM $\mathrm{PM}_{1}$ cyclone was installed in the common inlet line for the aerosol optical measurements. The rest of the instrumentation kept sampling total suspended particles (TSP). The sample air was dried by diffusion driers filled with silica gel to guarantee a relative humidity around $40 \%$ or below. An automatic regenerating adsorption aerosol dryer (Tuch et al., 2009) was installed in January 2015.

Another sampling site, the ZF2/TT34 tower, located $60 \mathrm{~km} \mathrm{NNW}$ of Manaus and $\sim 140 \mathrm{~km} \mathrm{WSW} \mathrm{of} \mathrm{ATTO}$ (Fig. S2), has been the location of long-term aerosol observations and intensive measurement campaigns (Martin et al., 2010a; Rizzo et al., 2013). Given that most of the air masses that reach the ZF2 site are similar to those transported over the ATTO site (C. Pöhlker et al., 2018), the ZF2 data are usually comparable to the ATTO data and the time series presented in this study can complement previous ZF2 time series already reported for the period 2008-2011 (Rizzo et al., 2013). Additionally, two intensive observation periods (IOP) and long-term measurements of the GoAmazon2014/5 experiment took place at several measurement sites in the Amazon Basin, including the ATTO site. More details can be found in Martin et al. (2016, 2017).

\subsection{Instrumentation}

\subsubsection{Aerosol light scattering measurements}

Scattering coefficients at ATTO were measured using different nephelometers. Figure S3 shows the measurement periods of the different instruments. The first one was a threewavelength integrating nephelometer (model 3563, TSI, St. 
Paul, USA) (14 August 2012 to 24 November 2013). The instrument measures aerosol scattering $\left(\sigma_{\mathrm{sp}}\right)$ and backscattering $\left(\sigma_{\mathrm{bsp}}\right)$ at 450,550 , and $700 \mathrm{~nm}$ (Anderson et al., 1996). Calibrations were periodically done by using $\mathrm{CO}_{2}$ as a span gas. Given the optical configuration of the instrument, the truncation of forward scattered radiation constitutes the largest source of error and was corrected by following the procedure described by Anderson et al. (1996). The estimated error of the nephelometer measurements is $8 \%$ for scattering coefficients on the order of $10 \mathrm{M} \mathrm{m}^{-1}$ (Rizzo et al., 2013). Using an averaging time of $30 \mathrm{~min}$, the detection limit at $550 \mathrm{~nm}$ was $0.14 \mathrm{M} \mathrm{m}^{-1}$ (Rizzo et al., 2013).

Later, in February 2014, the TSI nephelometer was replaced by an Aurora 3000 (Ecotech Pty Ltd., Knoxfield, Australia), which measures at 450,525 , and $635 \mathrm{~nm}$ wavelength. Over the measurement period studied in this work, we used two different Aurora instruments, with and without backscattering measurement. The Aurora nephelometer was set up to work with an integration time of $1 \mathrm{~min}$. Similar to the TSI nephelometer, $\mathrm{CO}_{2}$ calibrations were periodically performed. The data were corrected for truncation according to Müller et al. (2011b). Uncertainty in scattering measurements by the Aurora nephelometers was estimated to be $5 \%$ (Müller et al., 2011b).

\subsubsection{Aerosol light attenuation and absorption measurements}

Light absorption coefficients at $637 \mathrm{~nm}$ wavelength, $\sigma_{\mathrm{ap}, 637}$, were measured by a multi-angle absorption photometer, (MAAP, model 5012, Thermo Electron Group, Waltham, USA). This instrument measures the transmission of light through a glass-fiber filter on which aerosol particles are collected. Additionally to the forward hemisphere transmission measurement, the MAAP measures the light back scattering at 130 and $165^{\circ}$. By using a radiative transfer model (Petzold and Schönlinner, 2004), the instrument is able to provide absorption coefficients. The instrument was set up to provide data at $1 \mathrm{~min}$ resolution. By averaging the data at $30 \mathrm{~min}$ intervals, the MAAP detection limit is $0.13 \mathrm{M} \mathrm{m}^{-1}$, which corresponds to a $\mathrm{BC}_{\mathrm{e}}$ mass concentration of $20 \mathrm{ng} \mathrm{m}^{-3}$ (calculated with a MAC of $6.6 \mathrm{~m}^{2} \mathrm{~g}^{-1}$ ). The MAAP was generally operated at a flow rate of $10 \mathrm{~L} \mathrm{~min}^{-1}$, but for some periods the flow rate was reduced to $8.3 \mathrm{~L} \mathrm{~min}^{-1}$. According to Müller et al. (2011a), the MAAP measures at a wavelength of $637 \pm 1 \mathrm{~nm}$, instead of the $670 \mathrm{~nm}$ reported in the instrument's manual. In our calculations, we use $637 \mathrm{~nm}$ as the default MAAP wavelength and do not apply any interpolation factor to scale up the data from 670 to $637 \mathrm{~nm}$ since it would be within the instrument's $\sim 5 \%$ uncertainty range. The total uncertainty of the MAAP absorption measurements is of the order of $10 \%$ for 30 min average times (Rizzo et al., 2013).

An aethalometer was used to measure attenuation of light by aerosol particles at different wavelengths. This instrument uses an LED light source to irradiate an aerosol-laden quartz- fiber filter and a detector, located in the forward hemisphere, to measure the light transmission (Hansen et al., 1984). The measured transmission is compared to a blank measurement in order to obtain a change in light transmission (i.e., attenuation). This attenuation is then converted to $\mathrm{BC}$ mass concentration by using a mass attenuation cross section that depends on the instrument model (14625 and $6837.6 \mathrm{~m}^{2} \mathrm{~g}^{-1} \lambda^{-1}$ for the AE31 and AE33 aethalometer models, respectively).

Aethalometer measurements started at the ATTO site in April 2012 using model AE31 (Magee Scientific, Berkeley, USA). The instrument was operated at different flow rates during the measurement period (varying from 2.0 to $3.7 \mathrm{~L} \mathrm{~min}^{-1}$ ) and measured attenuation every $15 \mathrm{~min}$. In January 2015, a new aethalometer, model AE33 (Aerosol d.o.o., Ljubljana, Slovenia), was installed. The overlapping measurement time of the AE31 and AE33 models (27 November to 15 December 2014) enabled the comparison of both data sets. We found good agreement between both models (difference $<10 \%$ ) for measurements at 470, 520, 590, and $660 \mathrm{~nm}$. However, the wavelength dependence did not fit very well during this intercomparison period. Similar deviations in the wavelength dependence of AE31 and AE33 have been reported previously (ACTRIS, 2014). Nevertheless, it is still not clear whether the higher wavelength dependence of the AE33 compared to the AE31 is the result of an artifact of the instrument. An independent multi-wavelength absorption measurement can help to clarify the aforementioned AE31-

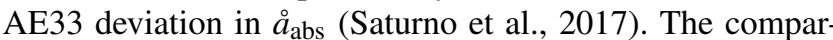
ison between compensated AE31 and AE33 data was used to correct the AE33 wavelength dependence deviation by applying intercomparison factors to AE33 data. The obtained AE31-AE33 intercomparison fits are shown in Fig. S4.

Aethalometer data require several corrections to account for different artifacts related to multiple scattering by the filter fibers, scattering by embedded aerosol particles, and filter-loading effects. The correction applied in this study has been described in a previous article (Saturno et al., 2017). The compensation algorithm is based on the correction scheme proposed by Collaud Coen et al. (2010). It uses MAAP data as a reference absorption measurement, which could introduce uncertainties related to the modification that aerosol particles can suffer by being deposited on a filter matrix. We retrieved the $\stackrel{\circ}{a b s}_{\text {abs }}$ from applying a $\log -\log$ fit to aethalometer data corrected for filter-loading and multiple scattering effects. In the case of aethalometer AE33, the measurements do not require a filter-loading correction because this model uses the dual-spot technology which accounts for this artifact (Drinovec et al., 2015). The AE33 internal algorithm applies a multiple scattering correction using the correction factor reported by Weingartner et al. (2003). In this study, this compensation was reverted and the multiple scattering correction was calculated according to a comparison with MAAP measurements, in a similar fashion to the one applied to AE31 data mentioned above. 


\subsection{3 rBC mass measurements and MAC calculations}

Refractory black carbon (rBC) was measured using a single particle soot photometer (SP2) revision C (Droplet Measurement Technologies, Longmont, USA). Initially, the measurements were done with a four-channel SP2 and the instrument was upgraded on 19 January 2015 to the eightchannel configuration. Figure S3 shows the different measurement periods of this instrument. The SP2 uses a highintensity Nd:YAG laser beam $\left(1 \mathrm{MW} \mathrm{cm}^{-2}, \lambda=1064 \mathrm{~nm}\right)$ to irradiate aerosol particles that are provided by an air jet at $90^{\circ}$, with a flow rate of $0.12 \mathrm{~L} \mathrm{~min}^{-1}$. All particles scatter the light from the laser beam and some of them, which are able to absorb radiation at the given wavelength (e.g., rBC), will incandesce and vaporize at high temperatures (Moteki and Kondo, 2008; Stephens et al., 2003). Four avalanche photo-diode (APD) detectors are installed in the instrument to measure (a) scattering, (b) broadband incandescence (350$800 \mathrm{~nm})$, (c) narrowband incandescence $(630-880 \mathrm{~nm})$, and (d) scattering with a split detector. Time-dependent data are recorded from each particle as it passes through the laser beam. The ratio between broadband and narrowband signals can provide information on the particle's composition since it is related to the boiling point temperature of the sampled particles (Schwarz et al., 2006). The instrument was periodically calibrated using fullerene soot (Alfa Aesar Inc.) as the $\mathrm{rBC}$ reference material. A quadratic fit was applied to the recorded incandescence peak heights vs. the mass of mobility size-selected fullerene particles. The fullerene effective densities were taken from Gysel et al. (2011). The scattering detector was calibrated using polystyrene latex (PSL) spheres by relating the scattering signal to the PSL scattering cross section. The SP2 rBC dynamic ranges were 80-280 and $80-450 \mathrm{~nm}$ for the four-channel and eight-channel configurations, respectively.

The narrow dynamic range of the four-channel SP2 was preventing us from measuring $\mathrm{rBC}$ mass concentration values comparable to MAAP measurements. In a comparison with another eight-channel instrument during the GoAmazon2014/5 experiment we found that the four-channel instrument was underestimating the $\mathrm{rBC}$ mass concentration by a factor of $40 \%$. This factor was stable during the wet season 2014, but we could not measure its stability during the following dry season. Due to instability of this factor over the sampling period, a proper data correction was not possible. Therefore, in this paper we use only the eight-channel instrument's data, which were available from 9 February 2015 until 31 July 2016 with some interruptions due to hardware failures. The eight-channel SP2 rBC size-dependent counting efficiency was obtained by comparing the counts of fullerene particles measured by the SP2 and a condensation particle counter (CPC). This way, an underestimation factor of $5 \%$ was found to affect SP2 rBC mass measurements and a scaling factor of 1.05 was applied to the data to account for this systematic error. Similar underestimation factors have been previously reported (Liu et al., 2017; Wang et al., 2014). The cumulative uncertainty of the SP2 measurements associated with the counting efficiency and mass calibration of the instrument has been estimated to be around $25 \%$ (Wang et al., 2014).

The BC mass absorption cross section, $\alpha_{\mathrm{abs}}$, was calculated by running daily fits of $30 \mathrm{~min}$ averaged MAAP $\sigma_{\mathrm{ap}, 637}$ vs. SP2 rBC mass concentration data, using a standardized major-axis estimation (as explained in Sect. 2.6). Fits with $R^{2}<0.9$ were filtered out, resulting in a total of 106 out of 220 days included in the final result. Given the mentioned SP2 and MAAP uncertainties, the $\alpha_{\text {abs }}$ values presented here have uncertainties around $\pm 40 \%$. The obtained $\alpha_{\text {abs }}$ values (shown in Sect. 3.1) were used to convert MAAP absorption measurements into $\mathrm{BC}_{\mathrm{e}}$ mass concentrations.

\subsubsection{Complementary measurements}

Online chemical composition of aerosol particles has been measured since August 2014 using an aerosol chemical speciation monitor (ACSM) (Aerodyne Research Inc., Billerica, USA). Initial results on non-refractory aerosol chemical composition at the ATTO site have already been reported by Andreae et al. (2015) and a detailed paper on the longterm ACSM observations is being prepared by Carbone et al. (2018). This online mass spectrometry technique detects organics, nitrate, sulfate, ammonium, and chloride in the submicron $(<1 \mu \mathrm{m})$ aerosol size range ( $\mathrm{Ng}$ et al., 2011).

A Picarro cavity ring-down spectrometer G1302 analyzer (Picarro Inc., Santa Clara, USA) measured $\mathrm{CO}_{2}$ and $\mathrm{CO}$ at the ATTO site. Three calibration tanks were used to calibrate the instrument every $100 \mathrm{~h}$. A Nafion ${ }^{\mathrm{TM}}$ dryer was installed in front of the instrument in order to reduce the noise in the $\mathrm{CO}$ measurements, which are affected by the high relative humidity of the tropical forest air. Calibration and performance checks will be reported in an upcoming paper. The instrument samples at five different heights, but we restrict our analysis to the data measured at $79 \mathrm{~m}$. All CO measurements have been conducted on the walk-up tower. The measurement setup is largely inspired by a setup operational at another location since 2009 (see Winderlich et al., 2010). In order to calculate the $\mathrm{BC}$ enhancement ratios with respect to $\mathrm{CO}\left(\mathrm{ER}_{\mathrm{BC}}\right)$, we used a major-axis estimation fit that was applied to the bivariate data (Falster et al., 2006) where the slope represents the enhancement ratio. The 5th percentiles were used as background values.

Condensation nuclei $(\mathrm{CN})$ number concentrations, $N_{\mathrm{CN}}$, and size distributions from $10 \mathrm{~nm}$ to $10 \mu \mathrm{m}$, were continuously measured using several instruments including mobility and optical particle sizers (more details can be found in Andreae et al., 2015). In this study, we used coarse mode $(>1 \mu \mathrm{m})$ number and mass concentrations obtained by means of an optical particle sizer (OPS), model 3330 (TSI Inc., Shoreview, USA), to identify mineral dust transport events. A detailed analysis of the Saharan dust plume 
arrivals at the ATTO site can be found in Moran-Zuloaga et al. (2018). Aerosol particle size distributions (10-430 nm diameter) were measured with scanning mobility particle sizer (SMPS) models 3080 and 3081 (TSI Inc., Shoreview, USA) using a CPC, model 3772 (TSI Inc., Shoreview, USA).

\subsection{Wavelength dependence and $\mathrm{BrC}$ contribution calculations}

Light scattering and absorption wavelength dependence are represented by the Ångström exponents, $\stackrel{\circ}{\text { sca }}_{\text {and }}$ abs, respectively. The Ångström exponent can be retrieved when measurements at two or more different wavelengths are available; for example, the $\stackrel{\circ}{a b s}_{\text {abs }}$ can be calculated as

$\stackrel{\circ}{\mathrm{abs}}_{\mathrm{a}}=-\frac{\ln \left(\frac{\sigma_{\mathrm{ap}}\left(\lambda_{1}\right)}{\sigma_{\mathrm{ap}}\left(\lambda_{2}\right)}\right)}{\ln \left(\frac{\lambda_{1}}{\lambda_{2}}\right)}$,

where $\sigma_{\text {ap }}$ is the absorption coefficient at two different wavelengths, $\lambda_{1}$ and $\lambda_{2}$.

When measurements at more than two wavelengths are available, a linear fit can be used to retrieve the Angström exponent from the logarithm of the absorption (or scattering) coefficients vs. the logarithm of the wavelength, as follows:

$\ln \sigma_{\mathrm{ap}}=-\stackrel{\circ}{\mathrm{abs}}_{\ln } \ln (\lambda)+\ln ($ constant $)$.

Black carbon is commonly taken to be wavelengthindependent with $\stackrel{\circ}{a}_{\text {abs }}=1$. However, this assumption is theoretically wrong and the BC-related $\stackrel{\circ}{a b s}_{\text {abs }}$ is very sensitive to the size of the particles (Moosmüller et al., 2011). Wang et al. (2016b) proposed a method to calculate the wavelength dependence of the Angström exponent (WDA) in order to estimate the $\mathrm{BrC}$ contribution to total light absorption by aerosol particles. They use the difference between two $\stackrel{\circ}{a b s}_{\text {abs }}$ calculated for two different wavelength pairs (440-870 and $675-880 \mathrm{~nm}$ ) using aerosol robotic network (AERONET) and aethalometer data. We use a similar approach to retrieve WDA using aethalometer data from the ATTO site. In this study the WDA is calculated as follows:

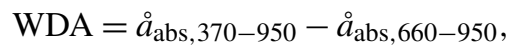

where $\stackrel{\circ}{a}_{a b s, 370-950}$ and $\stackrel{\circ}{a b s, 660-950}_{\text {correspond to the ab- }}$ sorption Ångström exponents calculated for the 370-950 and 660-950 nm wavelength pairs, respectively. This way, a theoretical BC WDA was calculated from the modeled $\stackrel{\circ}{a}_{\text {abs }}$ for $\mathrm{BC}(\mathrm{BC} \mathrm{WDA}=\stackrel{\circ}{\mathrm{a}} \mathrm{\textrm {abs }}, 370-950-\stackrel{\circ}{\mathrm{B}} \mathrm{\textrm {abs }}, 660-950)$.

Theoretical WDA values were calculated following conceptual Mie theory models for (i) polydisperse BC particles (Mishchenko et al., 1999), and (ii) core-shell internally mixed monodisperse BC (Bohren and Huffman, 1983). Characteristic BC core size distributions measured by the SP2 during the wet and dry seasons were used in the polydisperse BC-only model to retrieve extinction efficiency and single scattering albedo. The refractive indices used were 1.95-0.79i for BC (Bond and Bergstrom, 2006) and 1.55$0.001 \mathrm{i}$ for the coating material (Liu et al., 2015). The latter value was only used for the internally mixed BC case. The $\mathrm{BC}$ core diameters used in the internally mixed case were $100,125,150,175,200,225$, and $250 \mathrm{~nm}$, with a coating thickness to core size ratio from 0.1 to 1 . These values are in accordance with $\mathrm{rBC}$ mass size distributions observed at the ATTO site; see Fig. S5. Black carbon density was set to $1.8 \mathrm{~g} \mathrm{~cm}^{-3}$ (Schkolnik et al., 2007). Calculated BC WDA thresholds (25th and 75th percentiles), shown in Fig. S6, were compared to the ambient data in order to identify $\mathrm{BrC}$ influenced periods. For a general analysis, data with WDA lower than the 75 th percentile were considered to be in the $B C$-only regime. The presence of $\mathrm{BrC}$, in addition to $\mathrm{BC}$, occurred when the modeled $\mathrm{BC}$ absorption at $370 \mathrm{~nm}$ was exceeded. A sensitivity study of this model was done by changing the refractive indices and the core size of the model input. These results are presented in Table $\mathrm{S} 2$ as relative overestimation of the $\mathrm{BrC}$ contribution to $\sigma_{\mathrm{ap}, 370}$. The calculated BC absorption Ångström exponents $(\stackrel{\circ}{a} \mathrm{BC})$ for the two wavelength pairs mentioned in Eq. (3) were used to calculate $\mathrm{BrC}$ absorption at $370 \mathrm{~nm}$, as follows:

$\sigma_{\mathrm{ap}, 370}^{\mathrm{BC}}=\sigma_{\mathrm{ap}, 950} \times\left(\frac{370}{950}\right)^{-\stackrel{\mathrm{a}}{\mathrm{abs}, 370-950}^{\mathrm{BC}},}$

$\sigma_{\mathrm{ap}, 370}^{\mathrm{BrC}}=\sigma_{\mathrm{ap}, 370}-\sigma_{\mathrm{ap}, 370}^{\mathrm{BC}}$,

where $\stackrel{\circ \mathrm{BC}}{a}$ abs,370-950 is obtained from the Mie model calculations. The uncertainties of the $\mathrm{BrC}$ contribution to total absorption at $370 \mathrm{~nm}$ were calculated using the theoretical minimum and maximum BC WDA values. They were below $37 \%$ overall, and decreased to below $19 \%$ when the $\mathrm{BrC}$ contribution was higher than $30 \%$ at $370 \mathrm{~nm}$. The relative overestimation of the $\mathrm{BrC}$ contribution obtained by using different $\mathrm{BC}$ core sizes and different refractive indices in the Mie model calculations can be found in Table S2.

\subsection{HYSPLIT backward trajectories and clustering}

The systematic backward trajectory (BT) analysis used here is described in C. Pöhlker et al. (2018). Briefly summarized: three-day backward trajectories were calculated by running the NOAA hybrid single-particle Lagrangian integrated trajectory (HYSPLIT) model (Draxler and Hess, 1998) using $1^{\circ}$ resolution meteorological data from the global data assimilation system (GDAS1). The trajectories were calculated for $1000 \mathrm{~m}$ above ground level at $1 \mathrm{~h}$ intervals for the period January 2008 to June 2016. The entire trajectory ensemble was classified into $15 \mathrm{BT}$ clusters using a $k$ means cluster analysis. The clusters represent different air mass transport tracks and velocities. The different cluster average trajectories and their frequency of occurrence are 


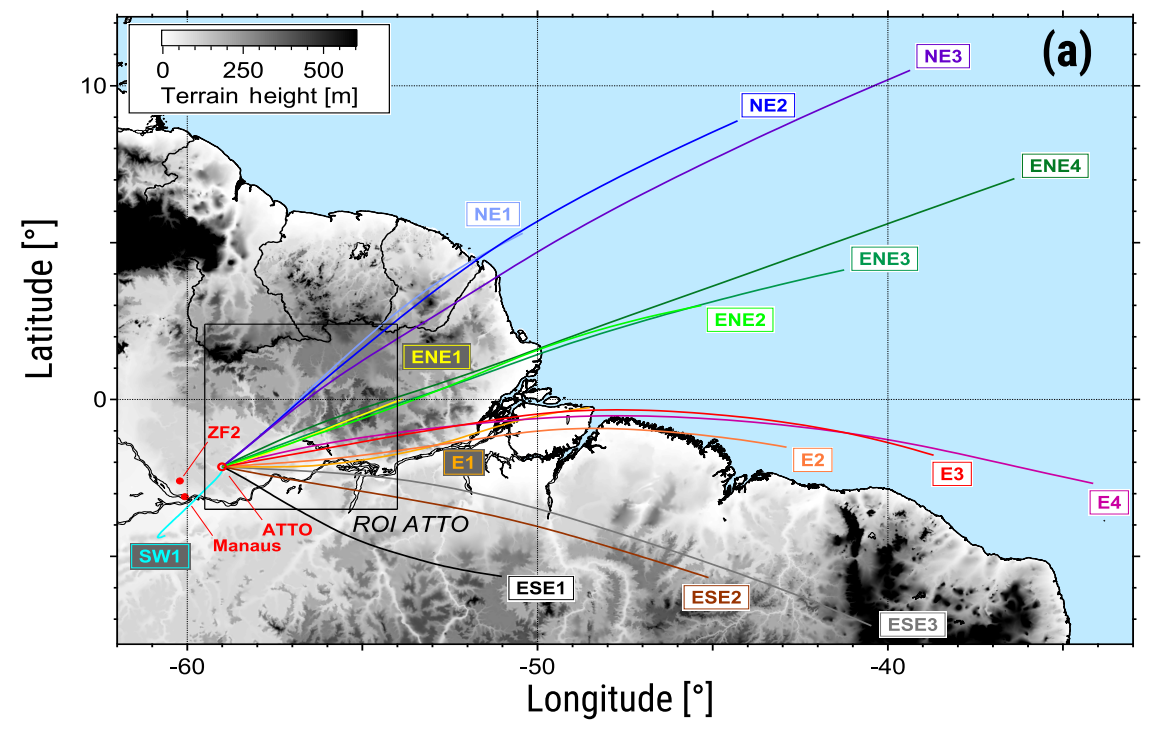

(b)

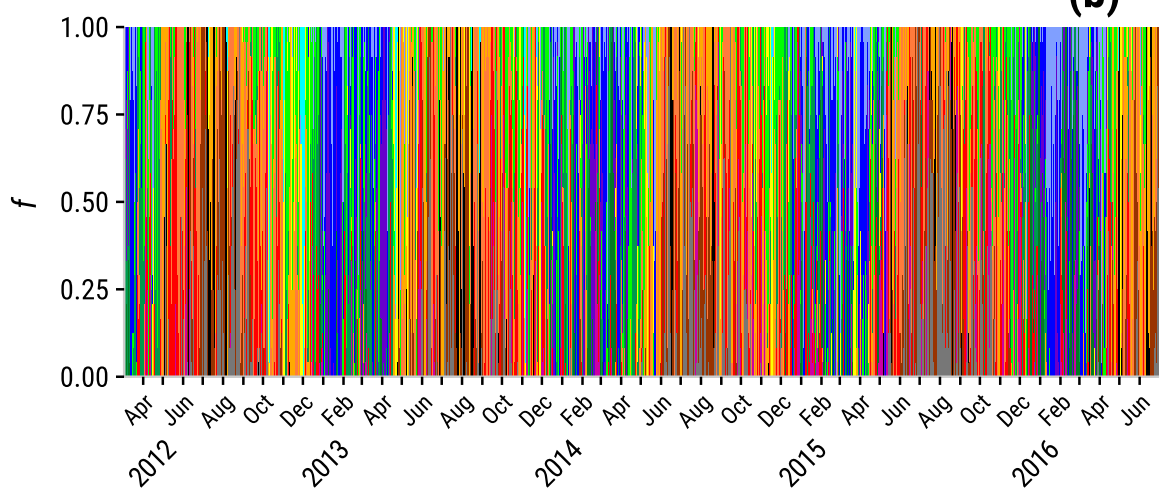

Figure 1. (a) Map of the northeastern Amazon Basin including averaged backward trajectory clusters and the region of interest (ROI) (59$54^{\circ} \mathrm{W} ; 3.5^{\circ} \mathrm{S}-2.4^{\circ} \mathrm{N}$ ), as a black rectangle, used to retrieve precipitation in the ATTO area. (b) Time series of the frequency of occurrence of each BT cluster during the sampling period. Adapted from C. Pöhlker et al. (2018).

shown in Fig. 1a and b, respectively. The clusters are classified as northeasterly ("NE1", "NE2", and "NE3"), eastnortheasterly ("ENE1", "ENE2", "ENE3", and "ENE4"), easterly ("E1", "E2", "E3", and "E4), southeasterly ("ESE1", "ESE2", and "ESE3"), and southwesterly ("SW1") trajectory clusters. In some parts of the analysis presented here the trajectory clusters are grouped by main directions (NE, ENE, E, and ESE).

South American fire count data were retrieved from the satellite observations database available online by the Instituto Nacional de Pesquisas Espaciais (INPE), Brazil, at https://prodwww-queimadas.dgi.inpe.br/bdqueimadas/, last access: 4 April 2017. The fire data covered the same period as the HYSPLIT clustering analysis period, January 2008 to June 2016. Fire counts were classified at hourly resolution according to the corresponding $\mathrm{BT}$ cluster where they occurred. The fire counts reported in this study were weighted according to the trajectory density as (trajectory counts) $/ 100 \mathrm{~km}^{2}$. Since the fire count number depends on the amount of satellite data available, we use these data with caution and only as a qualitative reference. For an extended discussion on fire geographical locations and land cover types, see C. Pöhlker et al. (2018).

\subsection{Satellite data}

The aerosol optical depth (AOD) at $550 \mathrm{~nm}$, measured by the moderate resolution imaging spectroradiometer (MODIS) onboard the satellites Terra and Aqua, was retrieved for two domains of interest (see Fig. 2a).

- DOI1: over the Atlantic Ocean. Used to monitor the westward transport of BB aerosol particles from southern Africa, which are mostly emitted during the Amazon dry season, especially between August and September (Das et al., 2017). There is no guarantee that the observed aerosol over this area will necessarily reach the 


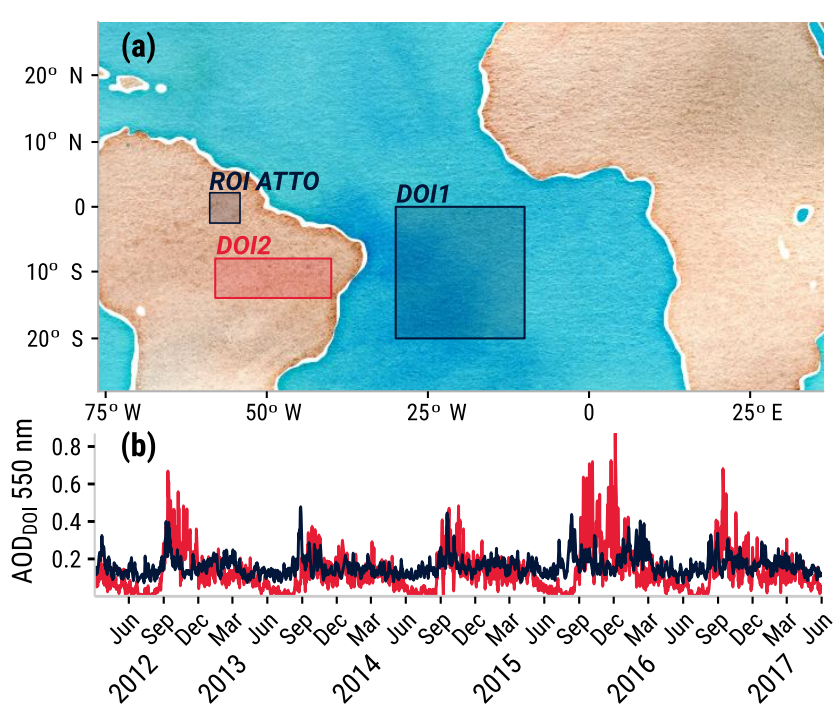

Figure 2. Aerosol optical depth $(550 \mathrm{~nm})$ observations in two different domains of interest shown in (a) DOI1 (boundaries: $30^{\circ} \mathrm{W}$; $20^{\circ} \mathrm{S} ; 10^{\circ} \mathrm{W} ; 0^{\circ} \mathrm{S}$ ) and DOI2 (boundaries: $58^{\circ} \mathrm{W} ; 14^{\circ} \mathrm{S} ; 40^{\circ} \mathrm{W}$; $\left.8^{\circ} \mathrm{S}\right)$. Time series of area-averaged AOD are shown in (b) for DOI1 (dark blue) and DOI2 (red). As a reference, the ATTO region of interest (ROI ATTO) is shown as a black rectangle in (a).

ATTO site, but it is used as an indication of LRT events from southern Africa that will likely reach the Amazon Basin.

Boundaries: $30^{\circ} \mathrm{W} ; 20^{\circ} \mathrm{S} ; 10^{\circ} \mathrm{W} ; 0^{\circ} \mathrm{S}$.

- DOI2: over the southern Amazon. Used to monitor BB in this region where fire activity is related to deforestation and agriculture-related activities.

Boundaries: $58^{\circ} \mathrm{W} ; 14^{\circ} \mathrm{S} ; 40^{\circ} \mathrm{W} ; 8^{\circ} \mathrm{S}$.

The MODIS products can be found online at the Goddard Earth Science Data and Information Services Center at https: //giovanni.gsfc.nasa.gov/giovanni/, last access: 17 July 2017, (GES-DISC, 2017).

Terra and Aqua data were averaged over the two different domains. The averaged AOD at $550 \mathrm{~nm}$ time series corresponding to DOI1 and DOI2 can be found in Fig. 2b. The seasonality observed for both data sets is similar, but the AOD for DOI1 (Atlantic Ocean) generally increased in August and decreased after the end of September, with some peaks in January-February, especially in 2016. On the other hand, high AOD values in DOI2 (southern Amazon) increased sharply in the beginning of September and decreased continuously until the middle of December, with the exception of the dry season 2015, when high AOD was observed until February 2016.

\subsection{Data treatment}

The analyzed data were averaged to $30 \mathrm{~min}$ intervals and corrected to standard temperature and pressure (STP, $273.15 \mathrm{~K}$ and $1013.25 \mathrm{hPa}$ ). Furthermore, the scattering data were interpolated to $637 \mathrm{~nm}$ to compare directly to the absorption data obtained by the MAAP, in order to avoid the uncertainty associated with the absorption spectral dependence calculation. The time periods of major and medium dust influence were taken from a study by Moran-Zuloaga et al. (2018). During the dry season, BB pulses were segregated by using the 75th percentile of $\sigma_{\mathrm{ap}} 637$ as a threshold. When examining correlations between independent measurements, we applied standardized major-axis estimations (SMA) by using the SMATR package (Falster et al., 2006) in the R statistical software environment (R Development Core Team, 2009). This method minimizes the error on the $x$ and $y$ axes, and not only at the $y$ axis, like a linear regression does. Therefore, it provides unbiased estimates of the slope (Warton et al., 2006).

\section{Results and discussion}

\subsection{Overview of aerosol optical properties (2012-2017)}

This section summarizes the aerosol optical properties from 5 years of continuous measurements at the ATTO site. The corresponding time series are shown in Fig. 3 and descriptive statistics can be found in Table 1 . The wet and dry season statistics were calculated excluding the transition periods.

The scattering coefficients, $\sigma_{\mathrm{sp}}$, are shown in Fig. 3a, averaging $7.5 \pm 9.3$ and $33 \pm 25 \mathrm{M} \mathrm{m}^{-1}$ at $550 \mathrm{~nm}$ during the wet and dry seasons, respectively (see Table 1). These values agree well with previously reported results at ZF2 of $8.1 \pm 7.2$ and $36 \pm 48 \mathrm{M} \mathrm{m}^{-1}$ at $550 \mathrm{~nm}$ during the wet and dry seasons, respectively (Rizzo et al., 2013). Good agreement was also found for our results at 450 and $700 \mathrm{~nm}$ and the corresponding data from Rizzo et al. (2003). The proximity of both sites, ATTO and ZF2, frequently allows probing of comparable air masses of similar origin and atmospheric history. The long-term measurements also show a pronounced yearto-year variability in $\sigma_{\mathrm{sp}}$ (compare, e.g., 2014 and 2015 in Fig. 3a). The largest observed deviations from the dry-season average were found during the dry season 2015 , with an average increase of $38 \%$ in $\sigma_{\mathrm{sp}}$ at $550 \mathrm{~nm}$. Similar increases were observed in $\sigma_{\mathrm{sp}}$ at 450 and $637 \mathrm{~nm}$. These increases can be directly related to the higher occurrence of fire episodes during the strong ENSO period 2015/2016 with its negative precipitation anomaly, as discussed in more detail in Sects. 3.5 and 3.6.

The absorption coefficients, $\sigma_{\mathrm{ap}}$, at $637 \mathrm{~nm}$ (MAAP) are shown in Fig. 3b, and averaged $0.68 \pm 0.91$ and $4.0 \pm$ $2.2 \mathrm{M} \mathrm{m}^{-1}$ during the wet and dry seasons, respectively. Also for this parameter, comparable values were measured at the ZF2 site, with averages of $1.0 \pm 1.4$ and $3.9 \pm 3.6 \mathrm{M} \mathrm{m}^{-1}$ at $637 \mathrm{~nm}$ during the wet and dry seasons, respectively (Rizzo et al., 2013). The higher increase in the absorption coefficient (factor of 5.9) from wet to dry season compared to 


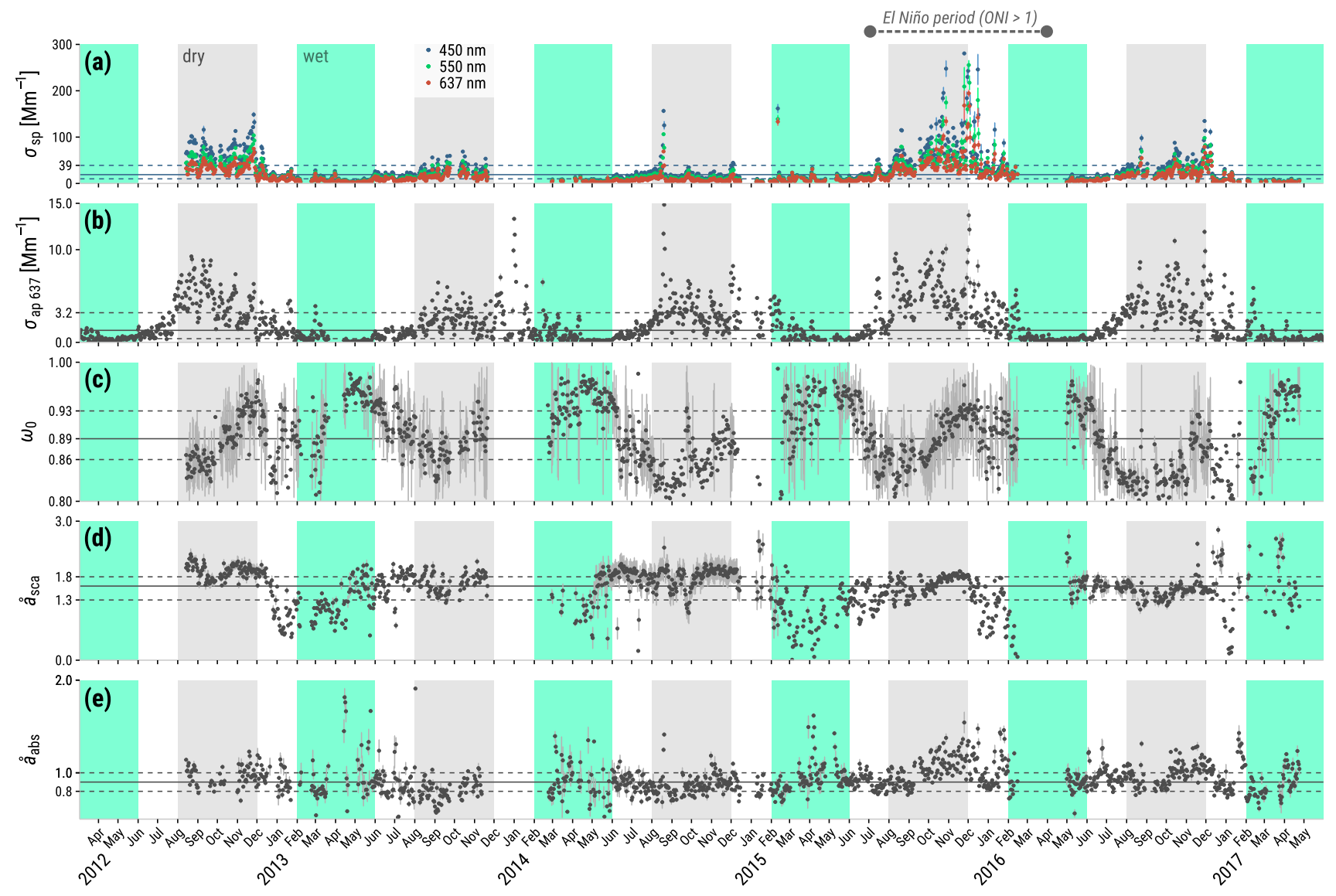

Figure 3. Overview of aerosol optical properties during the measurement period. (a) Scattering coefficient, (b) absorption coefficient at $637 \mathrm{~nm}$, (c) single scattering albedo at $637 \mathrm{~nm}$, (d) scattering Ångström exponent, and (e) absorption Ångström exponent. All data were averaged on $24 \mathrm{~h}$ intervals and standard errors are presented as vertical gray bars. Green and gray shaded areas correspond to the wet and dry seasons, respectively. First and third quartiles are represented as horizontal dashed lines, and medians as horizontal solid lines.

the increase in scattering (factor of 4.4) affected the $\omega_{0}$ (see Fig. 3c). Lower values were observed during the dry season $(0.87 \pm 0.03$ at $637 \mathrm{~nm}, 0.81 \pm 0.08$ at $550 \mathrm{~nm})$ compared to the averages observed in the wet season $(0.93 \pm 0.04$ at $637 \mathrm{~nm}, 0.88 \pm 0.08$ at $550 \mathrm{~nm})$. At the ZF2 site, Rizzo et al. (2013) have found small differences between $\omega_{0}$ values during the dry and wet seasons $(0.87 \pm 0.06$ and $0.86 \pm 0.09$ at $637 \mathrm{~nm}$, respectively) for over 2 years (2008-2011) of measurements. However, measurements during the wet season in 1998 at a sampling site closer to ATTO (Balbina, $60 \mathrm{~km} \mathrm{NW}$ of ATTO and $140 \mathrm{~km}$ NE of Manaus) showed higher $\omega_{0}$ values: $0.92-0.95$ at $550 \mathrm{~nm}$ (Formenti et al., 2001). These values are within our measurement range for the same season $(0.88 \pm 0.08$ at $550 \mathrm{~nm})$. Single scattering albedo retrieved from multi-year ground-based radiometer measurements in the Amazonian forest had an average of $0.93 \pm 0.02$ (Dubovik et al., 2002). Given that we sampled dried aerosol particles, our average $\omega_{0}$ are expected to be lower than these ambienthumidity values during the entire measurement period and the dry season. Measurements close to BB sources in Brazil have shown a wide range of $\omega_{0}$; e.g., Chand et al. (2006) found an $\omega_{0}$ of $0.92 \pm 0.02(550 \mathrm{~nm})$ for dried aerosol over Rondônia, whereas Guyon et al. (2003a) calculated lower $\omega_{0}$ values during $\mathrm{BB}$ events at the end of the LBA-EUSTACH 1 campaign in Rondônia, reaching $0.85 \pm 0.02$ at $550 \mathrm{~nm}$. Freshly emitted smoke has an even lower $\omega_{0}$, of $0.79 \pm 0.05$ at $550 \mathrm{~nm}$ (Reid et al., 1998).

The scattering Ångström exponent, $\stackrel{\circ}{\text { sca }}_{\text {}}$, is a function of the aerosol particle size distribution. However, some studies have found that this relationship is only evident for surface and volume mean diameters and was not clearly valid be-

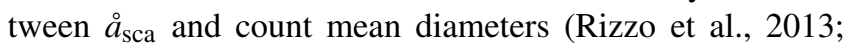
Virkkula et al., 2011). We obtained higher $\stackrel{a}{\text { sca }}_{\text {values dur- }}$ ing the dry season $(1.71 \pm 0.24)$ compared to the wet season $(1.29 \pm 0.50)$ as shown in Fig. 3d. This is an indication of the dominance of fine mode aerosol (mostly BB-related) during the dry season over the coarse mode aerosols that become more important in the wet season (i.e., PBAP, Saharan dust and sea salt), as previously observed at the ATTO site (Andreae et al., 2015; Moran-Zuloaga et al., 2018). A simi- 
Table 1. Descriptive statistics (mean \pm standard deviation and interquartile range, IQR) of daily averaged aerosol optical properties over the Amazon rainforest during the different seasons and the entire measurement period.

\begin{tabular}{|c|c|c|c|c|c|c|c|}
\hline & \multirow[b]{2}{*}{ Wavelength } & \multicolumn{2}{|c|}{$\begin{array}{l}\text { Wet season } \\
\text { (Feb-May) }\end{array}$} & \multicolumn{2}{|c|}{$\begin{array}{l}\text { Dry season } \\
\text { (Aug-Nov) }\end{array}$} & \multicolumn{2}{|c|}{$\begin{array}{l}\text { Entire period } \\
(2012-2017)\end{array}$} \\
\hline & & Mean \pm SD & IQR & Mean \pm SD & IQR & Mean \pm SD & IQR \\
\hline \multirow{3}{*}{$\begin{array}{l}\text { Scattering coefficient } \\
\sigma_{\mathrm{sp}}\left(\mathrm{M} \mathrm{m}^{-1}\right)\end{array}$} & $450 \mathrm{~nm}$ & $9 \pm 11$ & $(5.1-11)$ & $47 \pm 35$ & $(24-64)$ & $31 \pm 35$ & $(10-39)$ \\
\hline & $550 \mathrm{~nm}$ & $7.5 \pm 9.3$ & $(3.8-8.7)$ & $33 \pm 25$ & $(17-46)$ & $22 \pm 25$ & $(7-28)$ \\
\hline & $637 \mathrm{~nm}$ & $6.4 \pm 8.9$ & $(3.0-7.4)$ & $26 \pm 19$ & $(13-35)$ & $17 \pm 19$ & $(6-23)$ \\
\hline $\begin{array}{l}\text { Absorption coefficient } \\
\sigma_{\text {ap }}\left(\mathrm{M} \mathrm{m}^{-1}\right)\end{array}$ & $637 \mathrm{~nm}$ & $0.68 \pm 0.91$ & $(0.17-0.72)$ & $4.0 \pm 2.2$ & $(2.4-5.1)$ & $2.1 \pm 2.2$ & $(0.43-3.2)$ \\
\hline $\begin{array}{l}\text { Single scattering } \\
\text { albedo } \omega_{0}\end{array}$ & $637 \mathrm{~nm}$ & $0.93 \pm 0.04$ & $(0.91-0.96)$ & $0.87 \pm 0.03$ & $(0.84-0.89)$ & $0.89 \pm 0.04$ & $(0.86-0.93)$ \\
\hline $\begin{array}{l}\text { Scattering Ångström } \\
\text { exp. }{ }^{1} \stackrel{\circ}{\text { sca }}\end{array}$ & & $1.29 \pm 0.50$ & $(0.98-1.65)$ & $1.71 \pm 0.24$ & $(1.53-1.89)$ & $1.54 \pm 0.42$ & $(1.32-1.84)$ \\
\hline $\begin{array}{l}\text { Absorption Ångström } \\
\exp ^{1} \stackrel{\circ}{a}_{\mathrm{abs}}\end{array}$ & & $0.91 \pm 0.19$ & $(0.80-0.98)$ & $0.94 \pm 0.16$ & $(0.84-1.03)$ & $0.93 \pm 0.16$ & $(0.83-1.01)$ \\
\hline $\begin{array}{l}\text { Mass absorption } \\
\text { cross section } \\
\alpha_{\text {abs }}\left(\mathrm{m}^{2} \mathrm{~g}^{-1}\right)^{2}\end{array}$ & $637 \mathrm{~nm}$ & $11.4 \pm 1.2$ & $(10.8-12.0)$ & $12.3 \pm 1.3^{3}$ & $(11.4-13.3)^{3}$ & $11.9 \pm 1.4$ & $(11.0-13.0)$ \\
\hline
\end{tabular}

${ }^{1}$ Calculated by applying a log-log linear fit to measurements at all available wavelengths. ${ }^{2}$ Calculated by fitting eight-channel SP2 and MAAP data. ${ }^{3}$ Including data from July 2015/16 (wet-to-dry transition season).

lar seasonal trend has been observed at the ZF2 site, where $\stackrel{\circ}{\text { sca }}_{\text {was }} 1.70 \pm 1.41$ and $1.48 \pm 1.12$ (30 min averages) for the dry and wet seasons, respectively (Rizzo et al., 2013). A detailed analysis of the coarse mode aerosol abundance and properties measured at the ATTO site is presented elsewhere (Moran-Zuloaga et al., 2018).

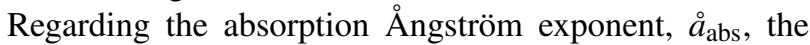
overall average during the whole sampling period was $0.93 \pm$ 0.16 (see Fig. 3e). Although no significant difference was found between dry and wet season averaged values, the aver-

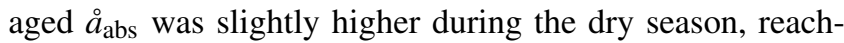
ing $0.94 \pm 0.16$ compared to $0.91 \pm 0.19$ during the wet season. It was found that the $\stackrel{a}{a b s}_{\text {abl }}$ only increased significantly during hours or days-long episodes, typically caused by nearby burning during the dry season. Details on the absorption wavelength dependence are discussed in Sect. 3.7. The aethalometer compensation calculation could potentially affect the retrieved $\stackrel{\circ}{a}_{\text {abs }}$ values. It has been shown that the raw attenuation Ångström exponent can represent a good ap-

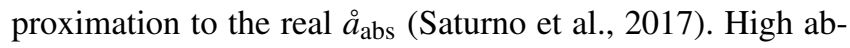
sorption and scattering coefficients coincide with ESE and E trajectories, which are mostly dominant, but not exclusively, during the dry season; see Fig. 1. On the other hand, during the "cleanest" periods in the wet season, when light absorption reaches its minimum and $\omega_{0}$ its maximum, the dominant trajectories are ENE and NE.

\subsection{Black carbon mass absorption cross section}

Accurate MAC values are required to retrieve $\mathrm{BC}$ mass concentrations from absorption measurements. During the entire measurement period, the calculated MAC was $11.9 \pm$ $1.4 \mathrm{~m}^{2} \mathrm{~g}^{-1}$ (mean \pm standard deviation) at $\lambda=637 \mathrm{~nm}$. Daily calculated MAC values in the wet season were slightly lower on average compared to the dry season values (11.4 \pm 1.2 and $12.3 \pm 1.3 \mathrm{~m}^{2} \mathrm{~g}^{-1}$, respectively; see Table 1). As an illustration of the different MAC values obtained in the wet and dry seasons, $\sigma_{\mathrm{ap}, 637}$ vs. $M_{\mathrm{rBC}}$ scatter plots are presented in the Supplement as Fig. S7. Lower MAC values measured in the wet season 2016 could be associated with less coated BC compared to more aged particles in the dry season, which could have thicker coatings. Nevertheless, both values are much higher than the $6.6 \mathrm{~m}^{2} \mathrm{~g}^{-1}$ suggested by Bond and Bergstrom (2006), especially considering that mineral dust and $\mathrm{BrC}$ do not strongly absorb at this wavelength and would therefore have little influence on the apparent MAC. However, they are in agreement with a modeled absorption enhancement of 1.6 calculated for open biomass burning in Brazil (Liu et al., 2017). In any case, there are large discrepancies that make it difficult to compare different MAC values obtained from ambient measurements due to systematic analytical uncertainties that dominate over the natural variability (Zanatta et al., 2016). These uncertainties are introduced by filter-based absorption measurement biases and $\mathrm{BC}$ mass overestimation or underestimation when 
thermal-optical methods are used. In the case of the SP2, the $\mathrm{rBC}$ mass measurements are free of the different biases that affect thermal-optical techniques and are a wavelengthindependent measurement. In the case of absorption measurements, a positive bias is introduced when organic aerosol deposits on the filter, enhancing the scattering by the filter fibers and the absorption by previously deposited $\mathrm{BC}$ particles when coating them. This artifact can be between $12 \%$ and $70 \%$ for particle soot absorption photometer (PSAP) measurements and will depend on the OA-to-BC ratio and the aging state of the organic aerosol particles (Lack et al., 2008). We expect a lower artifact for the MAAP since the scattering by filter fibers is accounted for by the reflectance measurements, but using our instrumentation we are not able to estimate the artifact coming from embedded BC absorption being modified by organic aerosol deposition. There are only a few field studies that present comparisons of rBC measurements and light absorption measurements, like MAAP, photoacoustic spectrometry (PAS), or aethalometer, and especially long-term measurements are scarce. Raatikainen et al. (2015) reported SP2 (eight-channel) and MAAP measurements in the Finnish Arctic and found that SP2 rBC mass concentrations were 5 times lower than MAAP $\mathrm{BC}_{\mathrm{e}}$ mass concentration measurements, which is equivalent to MAC values of $\sim 30 \mathrm{~m}^{2} \mathrm{~g}^{-1}$ at $637 \mathrm{~nm}$. Some other studies have found values in closer agreement with our ATTO MAC results. For example, Laborde et al. (2013) found that air masses over Paris had an average MAC of 11.9 and $10.8 \mathrm{~m}^{2} \mathrm{~g}^{-1}$ (interpolated to $637 \mathrm{~nm}$ ), for aged and fresh BB aerosol, respectively. Additionally, Liu et al. (2010) calculated a median MAC of $10.2 \pm 3.2 \mathrm{~m}^{2} \mathrm{~g}^{-1}$ during a measurement campaign at the Jungfraujoch research station in Switzerland. Another study in Mexico City, using PSAP for absorption measurements at $\lambda=660 \mathrm{~nm}$, found a MAC of $11.2 \mathrm{~m}^{2} \mathrm{~g}^{-1}$ (interpolated to $637 \mathrm{~nm}$ ) (Subramanian et al., 2010).

\subsection{Variability of optical properties during the dry season}

The Amazonian dry season is generally impacted by BB aerosol particles that cause an increase in scattering and absorption coefficients (see Fig. 3a-b). However, the aerosol optical properties vary with the burning material (and region), as well as the aging process prior to reaching the ATTO site. In order to study the dry season variability of BB aerosol particles, multi-year (2012-2017) weekly averages were analyzed. The air mass trajectories, presented as BT clusters in Fig. 4a, show a decreasing dominance of ESE winds from August to November, whereas from October to November there is an increasing influence of ENE winds, indicating the south-to-north air mass trajectory shift that occurs during the transition from the dry to wet seasons. It is important to note that southerly and easterly winds are most likely to bring BB aerosol to the ATTO site during

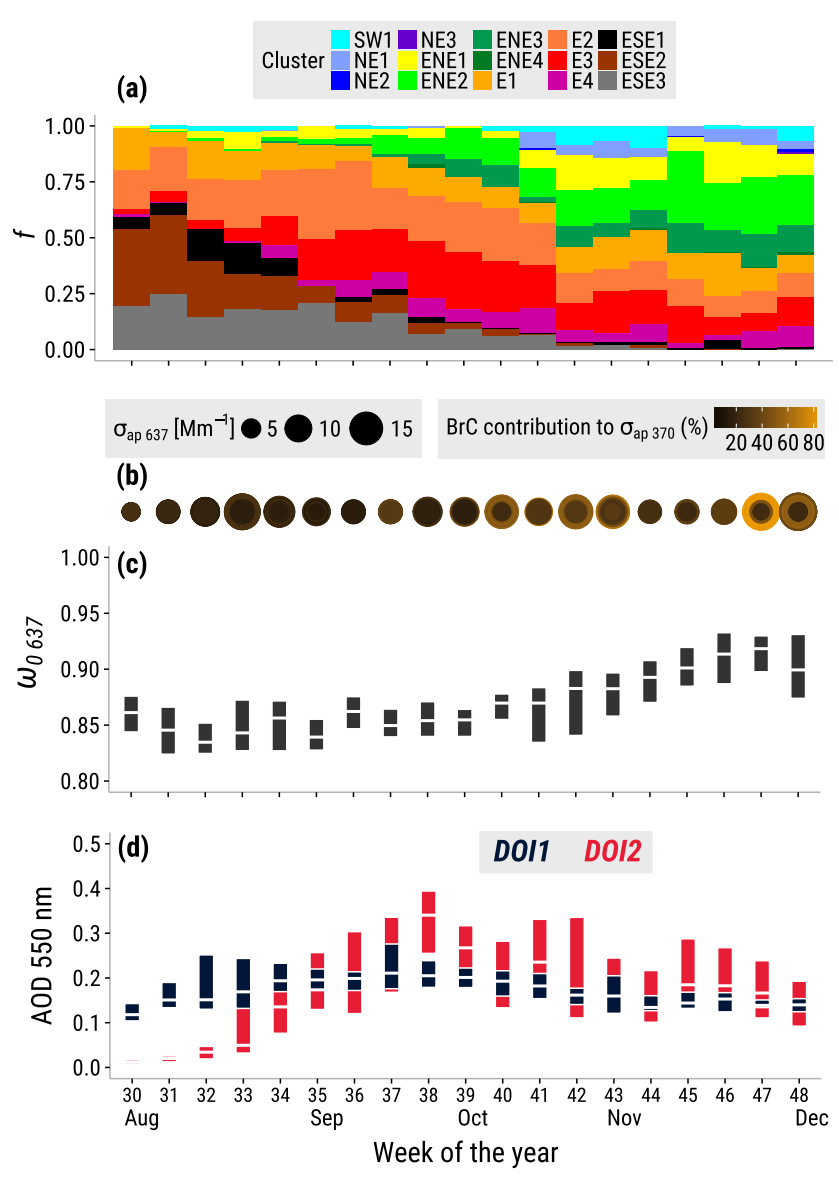

Figure 4. Multi-year (2012-2017) dry season weekly averages of (a) frequency of occurrence of BT clusters, $f$, (b) absorption co-

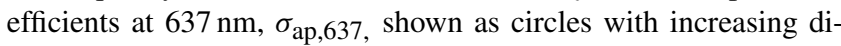
ameters, the color scale corresponding to the relative $\mathrm{BrC}$ contribution to $\sigma_{\mathrm{ap}, 370}$, (c) single scattering albedo at $637 \mathrm{~nm}, \omega_{0637}$, and (d) aerosol optical depth at $550 \mathrm{~nm}$ (AOD) for the different domains of interest, DOI1 and DOI2, which cover regions of the South Atlantic Ocean and the southern Amazon, respectively. Boxplots in (c) and (d) represent the median (white segment) and the 25th and 75th percentiles (lower and upper box edges, respectively).

the dry season, given that very active open fire areas during this period are located in the southern Amazon and the Cerrado region (Andreae et al., 2012; Guyon et al., 2005) and, more remotely, in southern Africa (Andreae et al., 1994; Barbosa et al., 1999; Das et al., 2017). Aerosol optical depth at $550 \mathrm{~nm}$ is used in this study as a parameter to study the seasonal pattern of BB emission transport from both areas. In Sect. 2.5, we defined two domains of interest to study the aerosol seasonal patterns in these two areas: DOI1 for the LRT of South African smoke over the Atlantic Ocean, and DOI 2 for the fires occurring in the southern Amazon. For the southern African fires (DOI1), the seasonal pattern shows an important influence during August-October, slightly decreasing towards the end of the Amazonian dry season (see Fig. 4d). For the southern Amazon region (DOI2), the typi- 
cal fire seasonality during the dry season is observed in the AOD over this area (Fig. 4d), with the highest values observed in September and October. It is important to note that August seems to be the period when African LRT is a more important source than regional emissions and could be considered the main contributor of BB aerosol to the ATTO site during this time. For the rest of the dry season, it is likely that the aerosol properties are defined by South American $\mathrm{BB}$ emissions. In fact, the shift in air mass trajectories and variation of $\mathrm{BB}$ sources drive the $\mathrm{BrC}$ contribution to $\sigma_{\mathrm{ap}, 370 \text {, }}$ as shown in Fig. 4b. The $\mathrm{BrC}$ contribution (associated with high $\stackrel{\circ}{a b s}_{\text {abs }}$ ) is more important at the end of the dry season and is lower during August, when the aerosol particles likely arrive from Zambian woodland savanna fires (Barbosa et al., 1999), which burn more efficiently and emit aerosol particles with lower $\omega_{0}, 0.84 \pm 0.015$ at $670 \mathrm{~nm}$ on average (Dubovik et al., 2002). Additionally, on average, high $\sigma_{\mathrm{ap}, 637}$ events (see the increasing circle size in Fig. 4b) are more likely to bring high $\mathrm{BrC}$ containing aerosol, which is another indication that closer fires have a higher probability of providing BrC-rich aerosol particles to the ATTO site. The absorption wavelength dependence and $\mathrm{BrC}$ contribution are discussed in detail in Sect. 3.6. The differences between both identified $\mathrm{BB}$ sources in terms of $\mathrm{BrC}$ can be explained by two reasons: (i) the $\mathrm{BrC}$ photochemical oxidation and destruction of chromophores during transport (Sumlin et al., 2017) that would strongly affect LRT aerosol, and (ii) a lower rain scavenging rate for $\mathrm{BC}$ during transport, which would lead to an increased $\mathrm{BC}$ fraction in the aerosol population. The increase in the single scattering albedo $\left(\omega_{0}\right.$, Fig. $\left.4 \mathrm{c}\right)$ towards the end of the dry season confirms that the aerosol particles during this time are scattering more radiation, not only due to higher $\mathrm{BrC}$ presence, but also due to other light-scattering aerosol particles.

\subsection{Diel cycles}

Figure 5 presents the diel cycles observed during the dry and the wet seasons for the following selected aerosol properties and meteorological parameters: Accumulation mode particle number concentration $\left(N_{\text {acc }}\right)$, absorption coefficient at $637 \mathrm{~nm}\left(\sigma_{\mathrm{ap}, 637}\right), \mathrm{BrC}$ absorption coefficient at $370 \mathrm{~nm}$ $\left(\sigma_{\mathrm{ap}, \mathrm{BrC}, 370}\right)$, precipitation rate $\left(P_{\mathrm{ATTO}}\right)$, and equivalent potential temperature $\left(\theta_{\mathrm{e}}\right)$. In order to study the typical diel cycles in each season, extreme events like mineral dust transport in the wet season and nearby BB during El Niño in 2015-2016 have been excluded by using data within the $90 \%$ confidence interval. The diel cycle of the equivalent potential temperature (Fig. 5i-j), calculated according to Stull (1988), reflects the evolution of the planetary boundary layer (PBL). Shortly before sunrise ( $\sim 10$ :00 UTC), $\theta_{\mathrm{e}}$ exhibits its minimum and increases afterwards reaching its maximum values in the early afternoon hours. The pronounced increase in $\theta_{\mathrm{e}}$ in the early morning hours reflects the onset of solar warming and the initiation of vertical mixing, leading to the evolution of the convective boundary layer. After sunset, a stable nocturnal boundary layer is formed close to the forest canopy. A detailed analysis of the planetary boundary layer of the Amazon can be found in Fisch et al. (2004). Figures 5a-b show diel cycles of accumulation mode (100$430 \mathrm{~nm}$ ) particle number concentration, $N_{\text {acc }}$. The diel patterns are similar during both seasons, with a minimum at sunrise, and an increase that starts in the morning at 12:00 UTC (08:00 LT) and maximum concentrations between 17:00 and 18:00 UTC (13:00-14:00 LT). This diel pattern observed in $N_{\text {acc }}$ is driven by the diurnal evolution of the planetary boundary layer. On the one hand, the stable nocturnal layer leads to a concentration of particles and gases close to the canopy. On the other hand, the canopy acts as an effective particle sink, resulting in a concentration decrease towards the early morning (Ahlm et al., 2009). After sunrise, vertical mixing breaks up the stable nocturnal boundary layer. While the subsequent increase in $N_{\text {acc }}$ is likely due to entrainment of particles from the elevated aerosol-rich layers, the decrease in the afternoon hours can be attributed to effective deposition in the forest canopy, as also discussed in Ahlm et al. (2009). The absorption coefficient at $637 \mathrm{~nm}$,

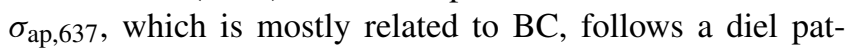
tern (Fig. $5 \mathrm{c}-\mathrm{d}$ ) similar to the $N_{\text {acc }}$ trend for both seasons. Since BC is usually not emitted by nearby sources and it is generally transported in the accumulation mode, the similarities with $N_{\text {acc }}$ diel patterns were expected. However, the wet season diel cycle of $\sigma_{\mathrm{ap}, 637}$ exhibits a decreasing tendency that starts two hours earlier than the decrease in $N_{\text {acc }}$. This difference can be explained by the fact that $\sigma_{\mathrm{ap}, 637}$ and $N_{\text {acc }}$ are mass and number-related measurements, respectively. Therefore, a size-dependent deposition would affect mass and number-related aerosol properties differently. This difference was more evident in the wet season when BC concentrations were not as dominant as in the dry season. The diel pattern of $\mathrm{BrC}$ contribution during the dry season is significantly different from the $\sigma_{\mathrm{ap}, 637}(\mathrm{BC})$ pattern. Brown car-

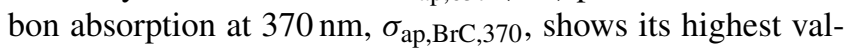
ues between 12:00 and 14:00 UTC (08:00-10:00 LT) in the dry season and starts decreasing at 14:00 UTC (10:00 LT), earlier than $\sigma_{\mathrm{ap}, 637}$ and $N_{\mathrm{acc}}$ (Fig. 5e). This observation implies that the $\mathrm{BrC}$ aerosol particles measured at the ATTO site are mixed down into the boundary layer in the early morning and are then quickly photo-degraded during the day (Forrister et al., 2015; Laskin et al., 2015; Rincón et al., 2010; Wang et al., 2016b; Wong et al., 2017). This pattern is not observed during the wet season, when $\sigma_{\mathrm{ap}, \mathrm{BrC}, 370}$ exhibits no significant diel variability.

Other remote site observations have found no significant diel variation of the absorption coefficient, due to efficient mixing of the PBL and low anthropogenic emissions (Chi et al., 2013). At ATTO, the high convectivity and related entrainment of high-altitude air masses, containing regional and/or LRT aerosols, result in a pronounced diel cycle in $\sigma_{\text {ap }}$. 

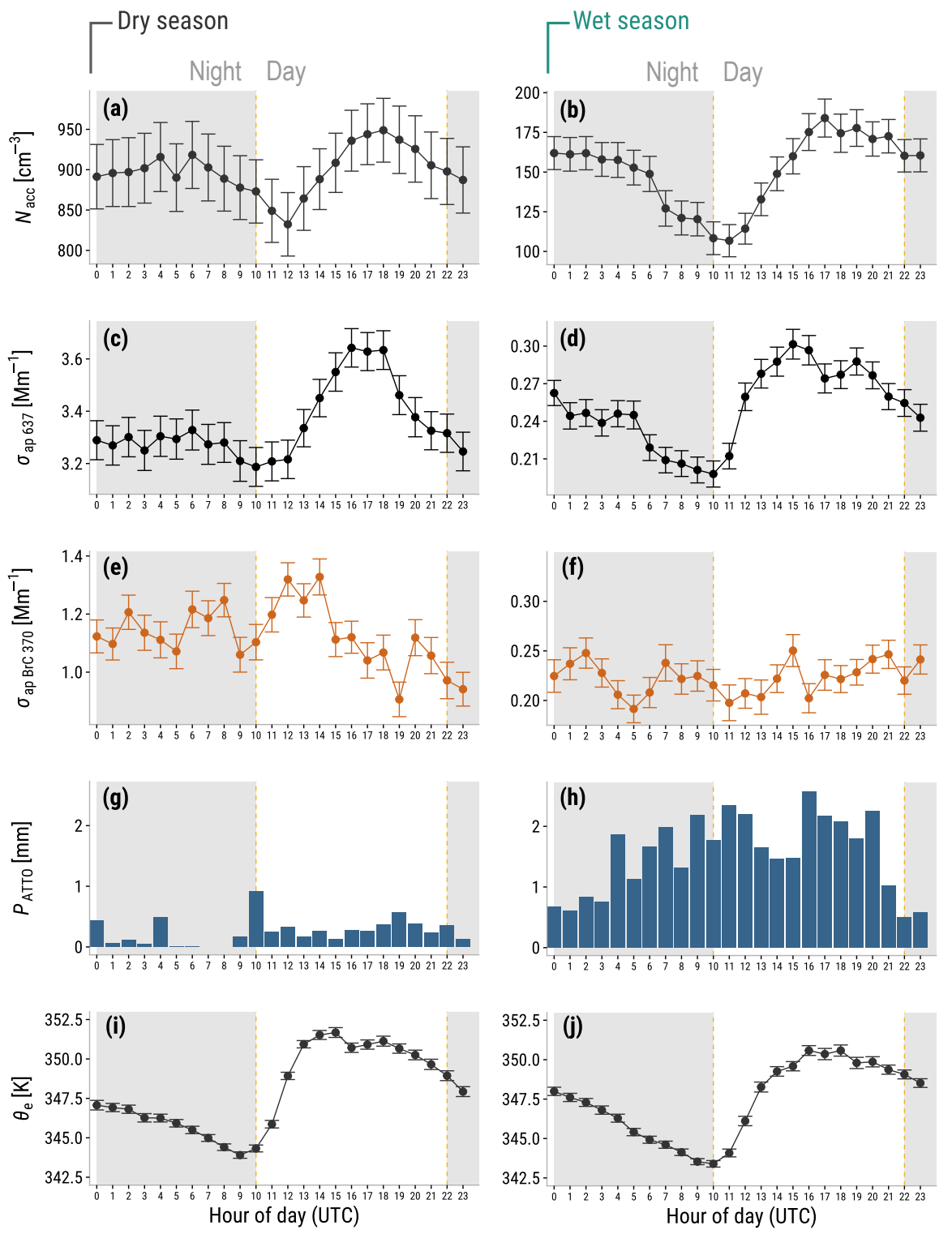

Figure 5. Diel variation of (a, b) median of the accumulation mode particle number concentration, $N_{\mathrm{acc}}$, (c, $\left.\mathbf{d}\right)$ median of the absorption coefficient at $637 \mathrm{~nm},(\mathbf{e}, \mathbf{f})$ median of the $\mathrm{BrC}$ absorption coefficient at $370 \mathrm{~nm},(\mathbf{g}, \mathbf{h})$ precipitation rate, and (i, j) median of the equivalent potential temperature. Gray and white backgrounds correspond to the night and day times, respectively. Error bars correspond to the standard error. Please note the different $y$ axis scales.

This is in good agreement with previous dry season results from another Amazonian site (Brito et al., 2014).

\subsection{BC-to-CO enhancement ratio}

Agricultural clearing fires, like savanna fires, are dominated by the flaming combustion phase, in contrast to deforestation fires, where less than $50 \%$ of the biomass is burned in the flaming phase (Dubovik et al., 2002). An important part of forest fires occurs in the form of smoldering combustion due to higher fuel moisture and larger fuel diameters (Guyon et al., 2005). Under smoldering fire conditions, when the combustion is less efficient and, thus, tends to emit more $\mathrm{CO}$, observations tend to show lower $\mathrm{ER}_{\mathrm{BC}}$ and higher single scattering albedo, $\omega_{0}$, as well as a higher organic carbon (OC) enhancement ratio, ER $\mathrm{OC}_{\mathrm{CC}}$. On the other hand, flaming fires, which produce abundant $\mathrm{BC}$ aerosol particles, tend to exhibit lower $\omega_{0}$ and higher $\mathrm{ER}_{\mathrm{BC}}$ (Akagi et al., 2011). The smoke that arrives at the ATTO site during the dry season is a mixture of smoldering and flaming emissions with varying relative fractions. The air mass origin (i.e., the backward trajectories) largely defines whether emissions are advected 
from regions with predominantly smoldering or flaming fires (C. Pöhlker et al., 2018).

The $\mathrm{ER}_{\mathrm{BC}}$ and $\omega_{0}$ values allow us to distinguish between flaming and smoldering-derived smoke and help locate the different sources. Figure 6 shows the $E_{B C}$ and $\omega_{0}$ values at ATTO, being classified by grouped BT clusters. Mainly, the ESE and E trajectory clusters have $\mathrm{ER}_{\mathrm{BC}}$ higher than $8 \mathrm{ng} \mathrm{m}^{-3} \mathrm{ppb}^{-1}$. From the two predominant BT cluster groups in the dry season (ESE and E), the ESE trajectories seem to be more influenced by flaming fires since the measurements are more shifted to high $\mathrm{ER}_{\mathrm{BC}}$ and lower $\omega_{0}$. In fact, the ESE clusters are dominated by the $0.80-0.90$ $\omega_{0}$ range, which means they are highly loaded with lightabsorbing aerosol. This is consistent with the land cover information, which indicates that agricultural lands account for $6 \%-20 \%$ of the ESE clusters' total land cover, 3\%-5\% of the E clusters, and $<1 \%$ of the ENE and NE clusters (C. Pöhlker et al., 2018). The eastern clusters (E) are more equally distributed in the $\omega_{0}$ range and tend to be lower in terms of $\mathrm{ER}_{\mathrm{BC}}$ compared to the ESE clusters. Therefore, we expect $\mathrm{E}$ trajectories to be more influenced by smoldering fires during the dry season compared to the ESE trajectories, even though, as already mentioned, the arrival of African savanna fire smoke from easterly trajectories in AugustSeptember provides BB aerosol particles that have lower $\omega_{0}$ and higher $\mathrm{ER}_{\mathrm{BC}}$.

During the wet season, when ENE and NE BT clusters are dominant, we observed a trend towards lower ER $_{\mathrm{BC}}$ and higher $\omega_{0}$, since the frequency of regional fires is much lower than in the dry season. Actually, when including data from the beginning of 2016, under the influence of ENSO, we observed a shift towards higher $\mathrm{ER}_{\mathrm{BC}}$ in the NE directions due to the occurrence of fires in the Guyanas area. These atypical data were excluded from Fig. 6 to improve the contrast between the different air mass trajectory clusters. The NE and ENE trajectories were very similar in terms of $\omega_{0}$ and $E R_{B C}$. Occasional dust transport events from the Sahara, mixed with BB aerosol from the Sahel region, brought aerosol particles with lower $\omega_{0}$ compared to the wet season average.

The lower $\mathrm{ER}_{\mathrm{BC}}$ observed in the wet season was likely due to aerosol scavenging during the transatlantic advection (Moran-Zuloaga et al., 2018), while CO is not affected by wet deposition (Liu et al., 2010). Note that ER $_{B C}$ decreased more steeply with increasing $\omega_{0}$, and their correlation was closer during the dry season (E and ESE BT clusters) in comparison to the wet season. This feature might be related to the age of the aerosol particles, because aging would make the BC become less hydrophobic (M. L. Pöhlker et al., 2018), so that it can be more efficiently removed by wet scavenging.

\subsection{El Niño impact on aerosol optical properties}

The aerosol optical properties measured at ATTO changed during the El Niño period at the end of 2015 and the beginning of 2016 (Fig. 3). To have a broader view of the relation-

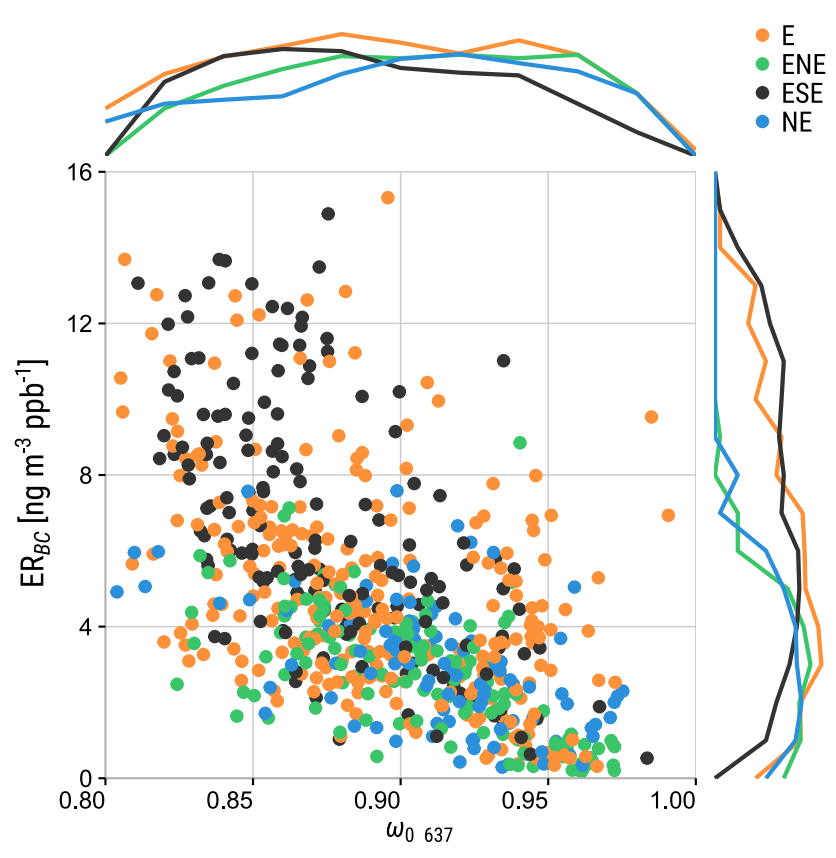

Figure 6. Scatter plot of 2012-2017 daily average of the BC-to-CO enhancement ratio, $\mathrm{ER}_{\mathrm{BC}}$ vs. single scattering albedo at $637 \mathrm{~nm}$, $\omega_{0} 637$, with marginal probability density plots (normalized counts in log scale) for data corresponding to grouped BT clusters.

ships between El Niño-related drought conditions, increased fire abundance, and the Amazonian aerosol properties, we added scattering and absorption data from the ZF2 site published in Rizzo et al. (2013) and extended with recent data to the current ATTO time series in Fig. 7a-b. Overlapping data in 2013 (Fig. 7a and b) are statistically equivalent, with only a few days affected by probable near-site sources. Positive Oceanic Niño Index (ONI) values (Fig. 7c) were found to be related to higher scattering and absorption coefficients in the dry season. However, the ENSO is not the only cause of precipitation anomalies in the Amazon Basin. The Atlantic Multi-Decadal Oscillation (AMO) has also been found to be causing droughts (Aragão et al., 2008). The non-ENSO daily mean average (ZF2 and ATTO) scattering coefficient at $637 \mathrm{~nm}$ during the dry seasons was $24 \pm 18 \mathrm{M} \mathrm{m}^{-1}$. This average increased up to $48 \pm 33 \mathrm{M} \mathrm{m}^{-1}$ during the ENSO periods (2009 and 2015 dry seasons). The wet season scattering coefficient average was also affected during El Niño, increasing from a non-ENSO average of $7 \pm 7$ to $10 \pm 11 \mathrm{M} \mathrm{m}^{-1}$ during the wet season 2016. A similar pattern was observed for $\sigma_{\mathrm{ap}, 637}$, which increased from a non-ENSO average in the dry seasons of $3.8 \pm 2.8 \mathrm{M} \mathrm{m}^{-1}$ to an ENSO average of $5.3 \pm 2.5 \mathrm{M} \mathrm{m}^{-1}$ (2009 and 2015 dry seasons' average). It is remarkable that high absorption coefficients were also measured during the dry season $2010\left(5.6 \pm 4.7 \mathrm{M} \mathrm{m}^{-1}\right)$, a year with a mostly negative ONI. However, it has been shown that an increased sea surface temperature in the Atlantic Ocean 

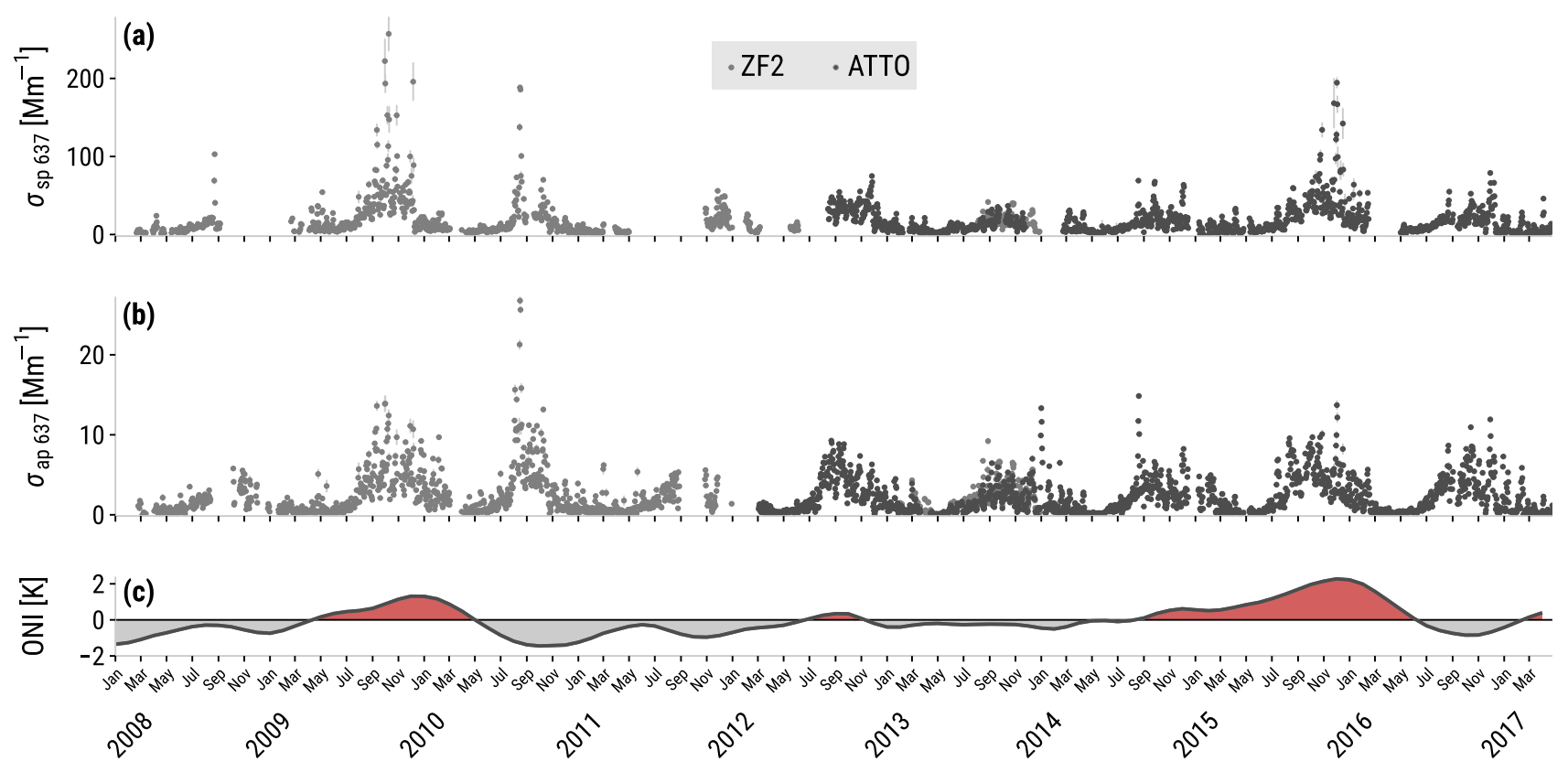

Figure 7. Scattering (a) and absorption (b) coefficient $(637 \mathrm{~nm}$ ) time series measured at the ZF2 and the ATTO sites from 2008 to 2016 ( $24 \mathrm{~h}$ averaged data). Increased scattering and absorption coefficients were observed under the influence of El Niño. (c) High ONI indicates active ENSO periods, shown as red shaded areas.

(not ENSO-related) in 2010 caused a special drought period in the Amazon rainforest (Lewis et al., 2011).

\subsection{Absorption wavelength dependence and $\mathrm{BrC}$ contribution}

Open biomass burning emits a mixture of $\mathrm{BC}$ and $\mathrm{OA}$ with high absorption wavelength dependence (Andreae and Gelencsér, 2006; Hoffer et al., 2006; Kirchstetter et al., 2004). However, our observations show that sometimes LAC measured at the ATTO site can fall in the BC-only regime, with $\stackrel{\circ}{a b s}_{\mathrm{abs}} \approx 1$. To understand this pattern, we have analyzed the relationship between the WDA and other parameters, like the OA-to-sulfate ratio and $\omega_{0}$. In Fig. 8a, WDA is presented as a function of the OA-to-sulfate mass ratio. According to the result of an orthogonal fit (not shown), there is a significant correlation between these variables $\left(R^{2}=0.61\right)$, and the aerosol light absorption is in the BC-only regime (shaded area in Fig. 8a) when the OA-to-sulfate ratio is lower than $\sim 6.5$, which occurred $15 \%$ of the time in the highabsorption periods ( $\sigma_{\mathrm{ap}, 637}$ higher than the 75 th percentile). On the other hand, higher OA-to-sulfate ratios correspond to likely $\mathrm{BrC}$-rich aerosol masses, which were the majority of the cases. The $\omega_{0}$ at $637 \mathrm{~nm}$ of the BC-only regime (interquartile range, IQR: $0.82-0.86$ ) was clearly lower than the one corresponding to the BrC-rich regime (IQR: 0.85-0.90).

In Fig. 8b, the BC-only regime data have been segregated by BT clusters. The air masses that are more likely to bring wavelength-independent LAC to the site are those with the faster wind speed: E3, E4, and ESE3. These emissions could be related to ship traffic in the Atlantic Ocean, BB in southern Africa, or power plant emissions from the western African coast. Low OA-to-sulfate ratios with high $\omega_{0}$ occurred a few times and could be explained by high sulfate input from volcanic emissions in the Congo (Fioletov et al., 2016; Saturno et al., 2018a), rather than fossil fuel emissions, which are typically rich in BC.

In an effort to identify the BrC-rich trajectories, the WDA was studied for the different BT clusters that are mostly active during the dry season. Box plots corresponding to each trajectory cluster, together with the average fire counts in the geographical cluster area, are presented in Fig. 9. From the group of ESE trajectory clusters (ESE1, ESE2, and ESE3), the ESE1 trajectories exhibit the highest WDA values, with a decreasing tendency towards faster trajectories, ESE3 being the one with the lowest WDA values. Even though ESE3 is the trajectory cluster with more fire counts, the fact that those fires occur farther from the ATTO site compared to the ones in the slowest trajectory, ESE1, could be related to a decrease in absorption wavelength dependence during transport. A similar pattern is observed for the easterly trajectory clusters (E1, E2, E3, and E4), where the slowest air mass trajectories comprised of the E1 cluster exhibit the highest WDA median compared to the rest of the E clusters. In the case of E4, the WDA 25th percentile is lower than the rest of the $\mathrm{E}$ trajectories, but it shows an increased median that can not be explained by the occurrence of fire events, which is 

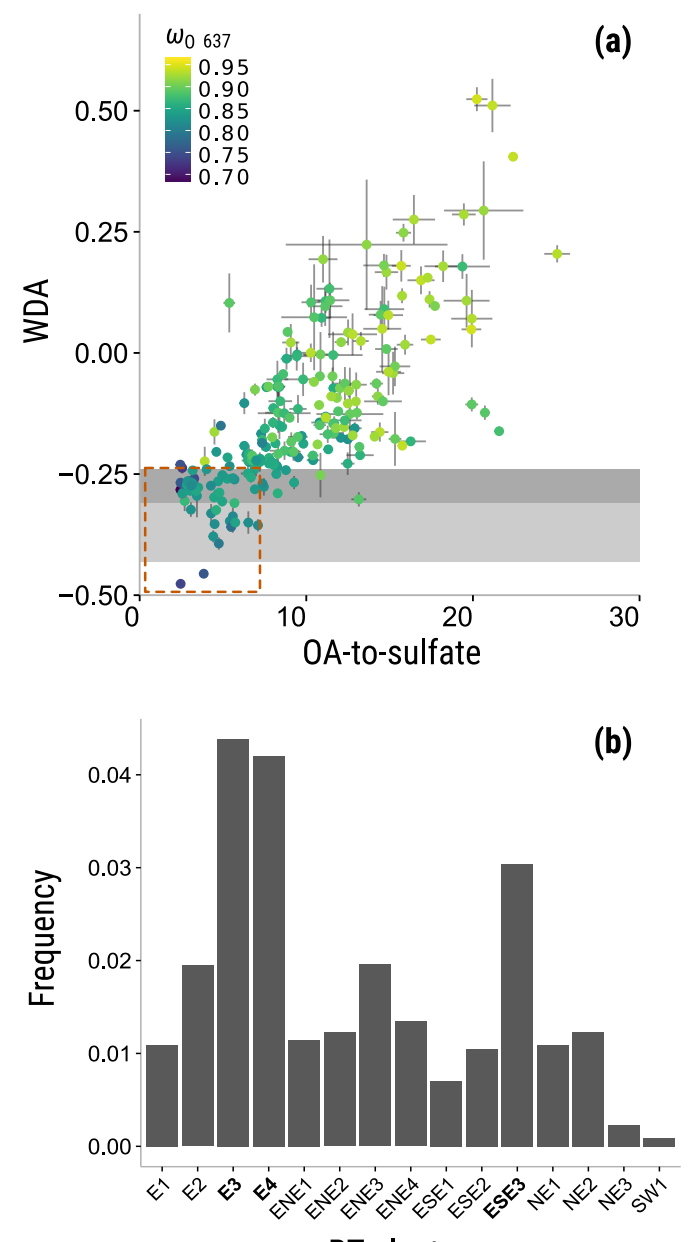

BT cluster

Figure 8. (a) Absorption wavelength dependence (WDA) as a function of the OA-to-sulfate mass ratio during high-absorption periods in the dry season. The color scale indicates the $\omega_{0}$ at $637 \mathrm{~nm}$. Gray shaded areas correspond to theoretical WDA for internally mixed BC (light gray) and externally mixed BC (dark gray). The data inside the dashed rectangle in (a) are used in (b) to identify the BT clusters that are more likely to bring wavelength-independent LAC to the ATTO site.

lower than the observations for the other clusters (E2, E3, and E4). The E4-weighted fire counts are anyhow on the same order of magnitude as E2 and E3 and the wavelength dependence differences could be related to different fuel types or combustion phases. Actually, the long E clusters (E3 and E4) cover more southern areas than the shorter ones (E1 and E2) and have some overlap with ESE3. By comparing grouped E and ESE clusters, it can be observed that WDA in the E clusters has higher variability compared to the ESE ones. This pattern could be associated with a wider range of sources in the $\mathrm{E}$ trajectories compared to ESE. The E trajectories travel over the Amazon River, where ship traffic is quite significant. In fact, as can be observed in Fig. 9, for the E3 and E4 trajectories, there is a significant number ( $>25$ th percentile)

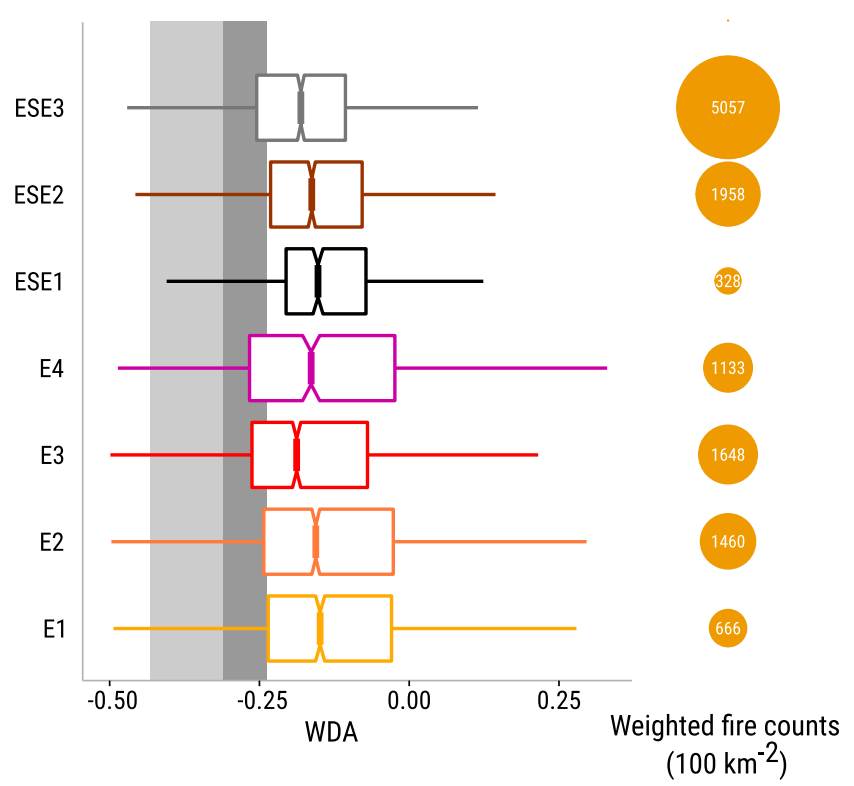

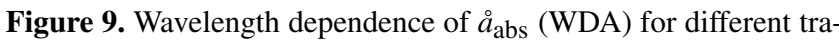
jectories in the dry season presented as box and whisker plots (left). The light and dark gray shaded areas correspond to the pure BC and internally mixed $\mathrm{BC}$ regimes, respectively. Notches correspond to $1.58 \mathrm{IQR} n^{-1 / 2}$. If notch ranges do not overlap, the medians are statistically different ( $95 \%$ confidence). The trajectory weighted fire counts for each BT cluster are shown as circles on the right side. The data presented here correspond to $1 \mathrm{~h}$ averages.

of measurements that fall in the BC-only regime. Something similar is only observed for the ESE3 trajectories among the ESE group. Most of the agricultural land is located along the southern margins of the Amazon rainforest (C. Pöhlker et al., 2018). This area is within the ESE clusters footprint. The narrower range of WDA values measured for the ESE trajectories compared to the E ones indicates that sources in the ESE footprint are more homogeneous compared to the sources located in the $\mathrm{E}$ footprint. These WDA tendencies could be useful for understanding the $\mathrm{BrC}$ emissions and atmospheric transformations in the context of the Amazon rainforest and its surroundings.

Using the calculated BC-only WDA thresholds, we were able to estimate the $\mathrm{BrC}$ contribution to total absorption during the measurement period (2012-2017) (Fig. 10). We found that $\mathrm{BrC}$ contributes $24 \%$ (IQR: $17 \%-29 \%$ ) of total light absorption at $370 \mathrm{~nm}$ wavelength. A slight seasonal variability was observed for the $\mathrm{BrC}$ relative contribution, with the medians and IQR during the wet and dry season being $27 \%$ (19-34) and $22 \%$ (16-27), respectively. However, most of the wet season data had to be excluded, because they were from air masses rich in mineral dust, which introduces large uncertainties into the WDA method. During El Niño, at the end of 2015, open fire events were more frequent (with weighted fire counts of $1756 \mathrm{~km}^{-2}$ compared to the 2008 2016 average of $1076 \mathrm{~km}^{-2}$ ), and the CO 95th percentile was 


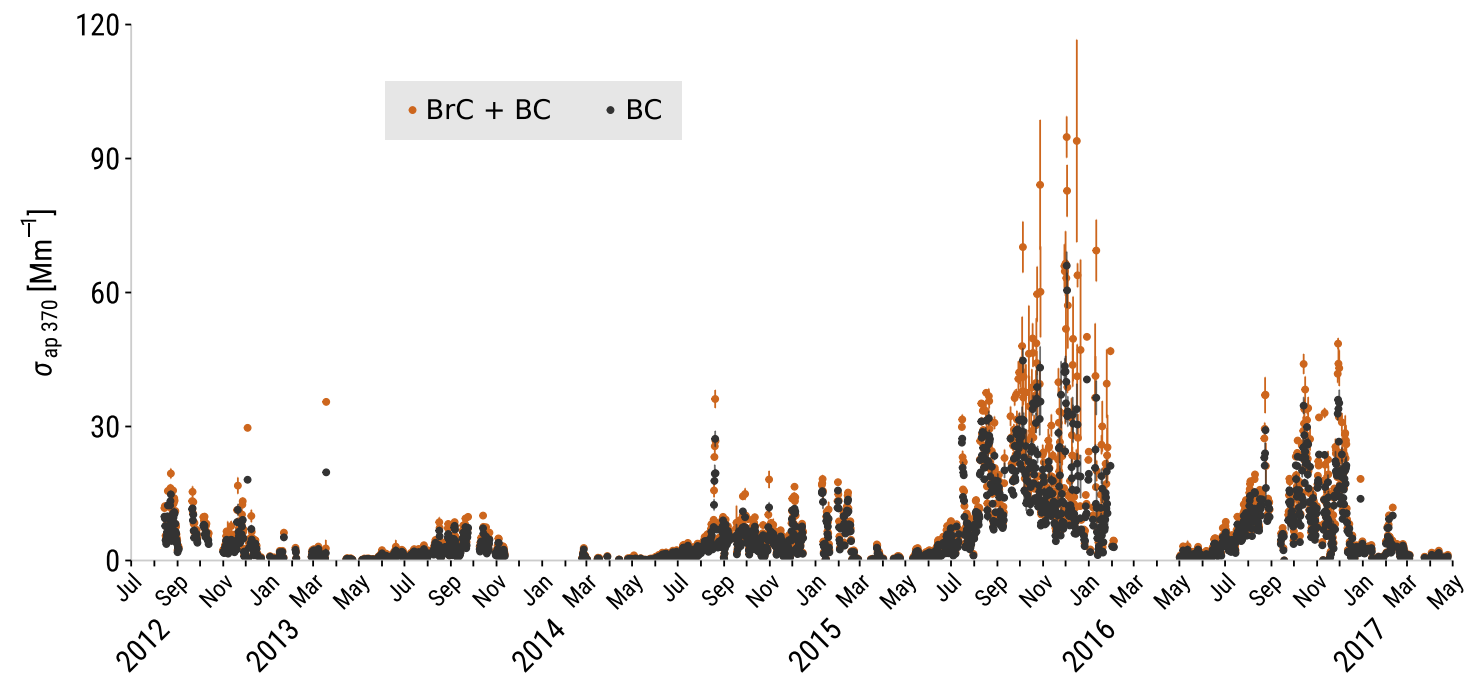

Figure 10. Total absorption at $370 \mathrm{~nm}$ ( $12 \mathrm{~h}$ average data) segregated by $\mathrm{BC}$ only (gray points) and $\mathrm{BrC}+\mathrm{BC}$ (brown points). Error bars are equivalent to \pm 1 standard error. Long-range transport dust events have been excluded from the analysis.

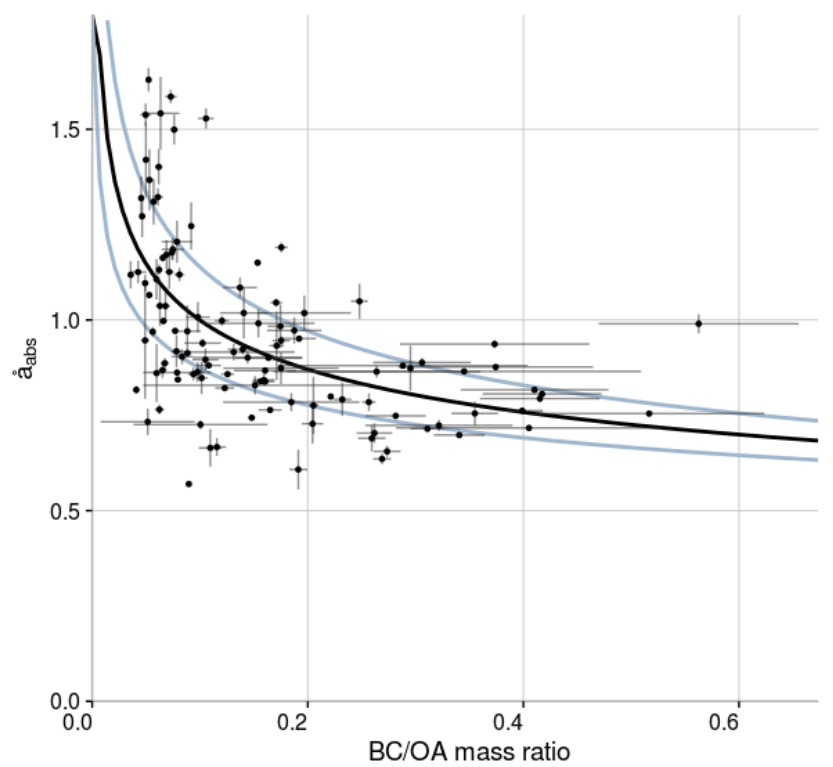

Figure 11. Absorption Ångström exponent $\left(\stackrel{\circ}{a b s}_{\text {abs }}\right)$ as a function of the $\mathrm{BC} / \mathrm{OA}$ mass ratio for selected dust events in the wet season. The black line corresponds to a non-linear least squares fit applied to the data $\left(y=x^{-0.199} \times 0.632\right)$. The light blue lines correspond to the standard error of the fit.

exceeded several times. In this period, the $\mathrm{BrC}$ contribution had a median of $37 \%$ (IQR: 27-47) and showed a significant correlation with $\mathrm{CO}\left(R^{2}=0.47\right)$. This significant increase in the $\mathrm{BrC}$ contribution could be related to the relatively short distance between the fire spots and the ATTO site. It can be observed in Fig. 10 that the El Niño influence continued during the dry season 2016, but not as strongly as in 2015. Previous observations have shown that the atmospheric lifetime of $\mathrm{BB}$-emitted $\mathrm{BrC}$ is $\sim 1$ day due to photolysis and oxidation, which destroy the chromophores (Forrister et al., 2015; Wang et al., 2016b; Wong et al., 2017). Therefore, BrC emitted from fires in the southern borders of the Amazon rainforest, which require $\sim 3$ days to be transported to the ATTO site, is likely to be significantly photodegraded and to contribute only weakly to total aerosol light absorption after atmospheric processing.

The BC-to-OA mass ratio during the sampling time had a median of 0.06 (IQR: 0.04-0.10). The ratio BC to OA has been used before to parameterize $\stackrel{\circ}{a}_{\text {abs }}$ and $\omega_{0}$ (Pokhrel et al., 2016; Saleh et al., 2014), but little is known about this relationship for tropical forest emissions. A broader range of the BC-to-OA mass ratio between 2014 and 2016 was observed during the dust episodes in the wet season, including those periods when regional fires were active (IQR: 0.08-0.24). Other periods, like the dry season, with higher BC mass concentrations exhibited a narrower and lower BC-to-OA mass ratio range (IQR: 0.03-0.08). A scatter plot of the absorp-

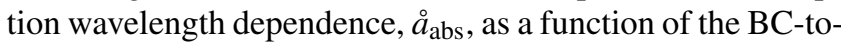
$\mathrm{OA}$ mass ratio during the northern African LRT events in the wet season can be found in Fig. 11. We have found a trend where $\stackrel{\circ}{a}_{\text {abs }}$ increases with decreasing BC-to-OA mass ratio following an exponential function. These results are comparable to those presented by Pokhrel et al. (2016) and Saleh et

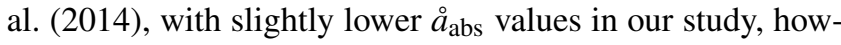
ever. This pattern could be related to a dominant presence of primary organic aerosol (POA) that has characteristically lower absorption wavelength dependence compared to SOA (Saleh et al., 2013). However, more experimental studies are required to investigate the optical properties of aerosol produced by burning different tropical forest fuels. 


\section{Summary and conclusions}

This study presents the optical properties of aerosol particles at the remote ATTO site for a measurement period of 5 years (2012-2017). The atmospheric seasonality at ATTO strongly affects aerosol light scattering and absorption, with significant increases from wet to dry season conditions due to intense biomass burning in South America and Africa. The wet season background aerosol was dominated by biogenic particles with occasional interruptions by long-range transported dust and BB aerosols from Africa to ATTO, leading to decreases in scattering Ångström exponent, $\stackrel{\leftrightarrow}{\text { sca }}_{\text {, }}$, and single scattering albedo, $\omega_{0}(637 \mathrm{~nm})$. The average $\omega_{0}$ during the wet season was $0.93 \pm 0.04$, which is higher than the dry season average of $0.87 \pm 0.03$. The absorption wavelength dependence, $\stackrel{\circ}{a}_{a b s}$, was relatively low, with an average of $0.93 \pm 0.16$, and varied only slightly between seasons. The highest $\stackrel{\circ}{a b s}_{\text {abs }}$ were measured during BB events, but no effect on $\stackrel{\circ}{a b s}_{\text {abs }}$ was observed due to the presence of dust, most likely due to a size effect, given that after May 2014 absorption coefficients were measured only for sub-micron aerosol particles. The BC mass absorption coefficient (MAC) at $637 \mathrm{~nm}$ calculated from MAAP and SP2 measurements agrees with other studies; however, it is higher than "typical" values that are commonly used in the literature to convert $\sigma_{\text {ap }}$ into $\mathrm{BC}$ mass concentrations. The calculated wet season MAC average was $11.4 \pm 1.2 \mathrm{~m}^{2} \mathrm{~g}^{-1}$, and increased slightly during the dry season to an average of $12.3 \pm 1.3 \mathrm{~m}^{2} \mathrm{~g}^{-1}$ at $637 \mathrm{~nm}$. These values are consistent with a strong "lensing effect" by organic coatings attached to $\mathrm{BC}$ aerosol particles. High OA amounts in the Amazonian atmosphere resulted in low BCto-OA mass ratios, in the range of 0.04 to 0.10 (IQR). A significant correlation between BC-to-OA mass ratio and $\stackrel{\leftrightarrow}{a}_{\text {abs }}$ was observed during the wet season under the influence of regional and remote $\mathrm{BB}$ emissions. The $\triangle \mathrm{BC} / \triangle \mathrm{CO}$ enhancement ratios $\left(\mathrm{ER}_{\mathrm{BC}}\right)$ were mostly lower than $8 \mathrm{ng} \mathrm{m}^{-3} \mathrm{ppb}^{-1}$, mainly due to the aging and deposition of $\mathrm{BB}$ aerosol particles during transport to ATTO. A higher and wider range of $\mathrm{ER}_{\mathrm{BC}}$ values was observed during the dry season due to the influence of different biomass combustion phases that varied from smoldering to flaming fires.
Theoretical wavelength-dependent $\mathrm{BC} \stackrel{\circ}{a}$ abs were calculated and used to estimate the $\mathrm{BrC}$ contribution to near-UV $(370 \mathrm{~nm})$ light absorption. This approach resulted in medians of $27 \%$ and $22 \% \mathrm{BrC}$ contributions in the wet and dry seasons, respectively. Higher $\mathrm{BrC}$ contributions were measured during the El Niño period at the end of 2015, when $\mathrm{BrC}$ absorption at $370 \mathrm{~nm}$ increased to a median of $37 \%$. We observed that winds coming from ESE directions in the dry season were more likely to bring aerosols with a high absorption wavelength dependence, implying a higher $\mathrm{BrC}$ content.

In the case of prolonged drought periods in the Amazon Basin, significant increases in $\mathrm{BrC}$ absorption contribution could be expected due to increased fire occurrence. Longterm monitoring of light absorbing aerosol particles is required to reduce uncertainty in global climate models. The data presented here provide a contribution in this direction and can help to understand how different climatic phenomena, like El Niño, can affect the Amazon atmospheric aerosol cycling. Further investigations on the $\mathrm{BC}$ mixing state and morphology will be required to improve modeled calculations and $\mathrm{BrC}$ retrievals.

Data availability. The data of the key results presented here have been deposited in supplementary data files for use in followup studies. They are available in NASA Ames format under https://doi.org/10.17617/3.1r (Saturno et al., 2018b, available data for ATTO BC and BrC study). For data requests beyond the available data, please refer to the corresponding authors. 


\section{Appendix A}

Table A1. List of frequently used symbols and acronyms.

\begin{tabular}{|c|c|c|c|}
\hline Description & Acronym & Symbol & Units \\
\hline Black carbon & $\mathrm{BC}$ & & \\
\hline Brown carbon & $\mathrm{BrC}$ & & \\
\hline Equivalent black carbon & $\mathrm{BC}_{\mathrm{e}}$ & & \\
\hline Refractory black carbon & $\mathrm{rBC}$ & & \\
\hline Organic carbon & $\mathrm{OC}$ & & \\
\hline Organic aerosol & $\mathrm{OA}$ & & \\
\hline Light-absorbing carbonaceous matter & LAC & & \\
\hline$\Delta \mathrm{BC} / \Delta \mathrm{CO}$ enhancement ratio & $\mathrm{ER}_{\mathrm{BC}}$ & & \\
\hline Attenuation coefficient & ATN & $\sigma_{\mathrm{ATN}}$ & $\mathrm{m}^{-1}$ \\
\hline Absorption coefficient & & $\sigma_{\mathrm{ap}}$ & $\mathrm{m}^{-1}$ \\
\hline Scattering coefficient & & $\sigma_{\mathrm{sp}}$ & $\mathrm{m}^{-1}$ \\
\hline Absorption Ångström exponent & AAE & $\stackrel{\circ}{a} \stackrel{\circ}{a b s}^{2}$ & \\
\hline Scattering Ångström exponent & SAE & $\stackrel{\circ}{a s c a}_{\text {sca }}$ & \\
\hline Wavelength dependence of $\stackrel{\circ}{a b s}$ & WDA & & \\
\hline Mass attenuation cross section & & $\alpha_{\text {atn }}$ & $\mathrm{m}^{2} \mathrm{~g}^{-1}$ \\
\hline (BC) Mass absorption cross section & MAC & $\alpha_{\mathrm{abs}}$ & $\mathrm{m}^{2} \mathrm{~g}^{-1}$ \\
\hline Backscattering coefficient & & $\sigma_{\mathrm{bsp}}$ & $\mathrm{m}^{-1}$ \\
\hline Single scattering albedo & SSA & $\omega_{0}$ & \\
\hline Aerosol optical depth & AOD & & \\
\hline Condensation nuclei number concentration $(>10 \mathrm{~nm})$ & & $N_{\mathrm{CN}}$ & $\mathrm{cm}^{-3}$ \\
\hline Accumulation mode particle number concentration $(100-430 \mathrm{~nm})$ & & $N_{\mathrm{acc}}$ & $\mathrm{cm}^{-3}$ \\
\hline Precipitation at ATTO region of interest (ROI), Fig. 1a & & $P_{\text {ATTO }}$ & $\mathrm{mm}$ \\
\hline Equivalent potential temperature & & $\theta_{\mathrm{e}}$ & $\mathrm{K}$ \\
\hline Amazon Tall Tower Observatory & ATTO & & \\
\hline Backward trajectory & BT & & \\
\hline Long-range transport & LRT & & \\
\hline El Niño-Southern Oscillation & ENSO & & \\
\hline Oceanic Niño Index & ONI & & \\
\hline Biomass burning & BB & & \\
\hline Fossil fuel & $\mathrm{FF}$ & & \\
\hline Coordinated universal time & UTC & & \\
\hline Local time & LT & & \\
\hline Inter-quartile range & IQR & & \\
\hline Domain of interest, Fig. 2a & DOI & & \\
\hline
\end{tabular}


Supplement. The supplement related to this article is available online at: https://doi.org/10.5194/acp-18-12817-2018-supplement.

Author contributions. JS, BAH, CP, FD, QW, DMZ, JB, SC, YC, XC, JVL, MLP, LVR, DW, SW, PA, UP and MOA designed the research. JS, BAH, CP, FD, QW, DMZ, JB, SC, YC, XC, JD, IHA, TK, JVL, HP, MLP, LVR, PS, DW, SW and MOA performed the measurements and/or contributed to the data analysis. All authors contributed to the discussion and interpretation of the results and to writing the paper.

Competing interests. The authors declare that they have no conflict of interest.

Special issue statement. This article is part of the special issues "Amazon Tall Tower Observatory (ATTO) Special Issue" and "Observations and Modeling of the Green Ocean Amazon (GoAmazon2014/5)". It is not associated with a conference.

Acknowledgements. This work has been supported by the Max Planck Society (MPG) and the Paul Crutzen Graduate School (PCGS). For the operation of the ATTO site, we acknowledge the support by the German Federal Ministry of Education and Research (BMBF contract 01LB1001A) and the Brazilian Ministério da Ciência, Tecnologia e Inovação (MCTI/FINEP contract 01.11.01248.00) as well as the Amazon State University (UEA), FAPEAM, LBA/INPA and SDS/CEUC/RDS-Uatumã. Paulo Artaxo acknowledges support from FAPESP - Fundação de Amparo à Pesquisa do Estado de São Paulo. Jorge Saturno is grateful for the $\mathrm{PhD}$ scholarship from the Fundación Gran Mariscal de Ayacucho (Fundayacucho). This paper contains results of research conducted under the Technical/Scientific Cooperation Agreement between the National Institute for Amazonian Research, the State University of Amazonas, and the Max-Planck-Gesellschaft e.V.; the opinions expressed are the entire responsibility of the authors and not of the participating institutions. We highly acknowledge the support by the Instituto Nacional de Pesquisas da Amazônia (INPA). We would like to especially thank all the people involved in the technical, logistical, and scientific support of the ATTO project, in particular Reiner Ditz, Jürgen Kesselmeier, Alberto Quesada, Niro Higuchi, Susan Trumbore, Matthias Sörgel, Thomas Disper, Andrew Crozier, Thomas Klimach, Björn Nillius, Uwe Schulz, Steffen Schmidt, Antonio Ocimar Manzi, Alcides Camargo Ribeiro, Hermes Braga Xavier, Elton Mendes da Silva, Nagib Alberto de Castro Souza, Adi Vasconcelos Brandão, Amaury Rodrigues Pereira, Antonio Huxley Melo Nascimento, Feliciano de Souza Coehlo, Thiago de Lima Xavier, Josué Ferreira de Souza, Roberta Pereira de Souza, Bruno Takeshi, and Wallace Rabelo Costa.

The article processing charges for this open-access publication were covered by the Max Planck Society.

Edited by: Markku Kulmala

Reviewed by: two anonymous referees

\section{References}

ACTRIS: ACTRIS Intercomparison Workshop for Integrating Nephelometer and Absorption Photometers, Leipzig, Germany, available at: http://www.wmo-gaw-wcc-aerosolphysics.org/files/ACTRIS-intercomparison-workshopintegrating-nephelometer-and-absorption-photometer-0203-2013.pdf (last access 1 June 2017), 2014.

Ahlm, L., Nilsson, E. D., Krejci, R., Mårtensson, E. M., Vogt, M., and Artaxo, P.: Aerosol number fluxes over the Amazon rain forest during the wet season, Atmos. Chem. Phys., 9, 9381-9400, https://doi.org/10.5194/acp-9-9381-2009, 2009.

Akagi, S. K., Yokelson, R. J., Wiedinmyer, C., Alvarado, M. J., Reid, J. S., Karl, T., Crounse, J. D., and Wennberg, P. O.: Emission factors for open and domestic biomass burning for use in atmospheric models, Atmos. Chem. Phys., 11, 4039-4072, https://doi.org/10.5194/acp-11-4039-2011, 2011.

Anderson, T. L., Covert, D. S., Marshall, S. F., Laucks, M. L., Charlson, R. J., Waggoner, A. P., Ogren, J. A., Caldow, R., Holm, R. L., Quant, F. R., Sem, G. J., Wiedensohler, A., Ahlquist, N. A., and Bates, T. S.: Performance Characteristics of a High-Sensitivity, ThreeWavelength, Total Scatter/Backscatter Nephelometer, J. Atmos. Ocean. Tech., 13, 967-986, https://doi.org/10.1175/15200426(1996)013<0967:PCOAHS>2.0.CO;2, 1996.

Andreae, M. O.: Biomass burning: Its history, use and distribution and its impact on environmental quality and global climate, Glob. Biomass Burn. Atmos. Clim. Biosph. Implic., 15-42, 1991.

Andreae, M. O.: Raising dust in the greenhouse, Nature, 380, 389390, https://doi.org/10.1038/380389a0, 1996.

Andreae, M. O.: The dark side of aerosols, Nature, 409, 671-672, https://doi.org/10.1038/35055640, 2001

Andreae, M. O.: Aerosols before pollution, Science, 315, 50-51, https://doi.org/10.1126/science.1136529, 2007.

Andreae, M. O. and Gelencsér, A.: Black carbon or brown carbon? The nature of light-absorbing carbonaceous aerosols, Atmos. Chem. Phys., 6, 3131-3148, https://doi.org/10.5194/acp-63131-2006, 2006.

Andreae, M. O. and Merlet, P.: Emission of trace gases and aerosols from biomass burning, Global Biogeochem. Cy., 15, 955-966, https://doi.org/10.1029/2000GB001382, 2001.

Andreae, M. O., Browell, E. V., Garstang, M., Gregory, G. L., Harriss, R. C., Hill, G. F., Jacob, D. J., Pereira, M. C., Sachse, G. W., Setzer, A. W., Dias, P. L. S., Talbot, R. W., Torres, A. L., and Wofsy, S. C.: Biomass-burning emissions and associated haze layers over Amazonia, J. Geophys. Res., 93, 1509-1527, https://doi.org/10.1029/JD093iD02p01509, 1988.

Andreae, M. O., Anderson, B. E., Blake, D. R., Bradshaw, J. D., Collins, J. E., Gregory, G. L., Sachse, G. W., and Shipham, M. C.: Influence of plumes from biomass burning on atmospheric chemistry over the equatorial and tropical South Atlantic during CITE 3, J. Geophys. Res., 99, 12793-12808, https://doi.org/10.1029/94JD00263, 1994.

Andreae, M. O., Artaxo, P., Beck, V., Bela, M., Freitas, S., Gerbig, C., Longo, K., Munger, J. W., Wiedemann, K. T., and Wofsy, S. C.: Carbon monoxide and related trace gases and aerosols over the Amazon Basin during the wet and dry seasons, Atmos. Chem. Phys., 12, 6041-6065, https://doi.org/10.5194/acp12-6041-2012, 2012. 
Andreae, M. O., Acevedo, O. C., Araùjo, A., et al.: The Amazon Tall Tower Observatory (ATTO): overview of pilot measurements on ecosystem ecology, meteorology, trace gases, and aerosols, Atmos. Chem. Phys., 15, 10723-10776, https://doi.org/10.5194/acp-15-10723-2015, 2015.

Ångström, A.: On the Atmospheric Transmission of Sun Radiation and on Dust in the Air, Geogr. Ann., 11, 156-166, https://doi.org/10.2307/519399, 1929.

Aragão, L. E. O., Malhi, Y., Roman-Cuesta, R. M., Saatchi, S., Anderson, L. O., and Shimabukuro, Y. E.: Spatial patterns and fire response of recent Amazonian droughts, Geophys. Res. Lett., 34, 1-5, https://doi.org/10.1029/2006GL028946, 2007.

Aragão, L. E. O., Malhi, Y., Barbier, N., Lima, A., Shimabukuro, Y., Anderson, L., and Saatchi, S.: Interactions between rainfall, deforestation and fires during recent years in the Brazilian Amazonia, Philos. Trans. R. Soc. B Biol. Sci., 363, 1779-1785, https://doi.org/10.1098/rstb.2007.0026, 2008.

Artaxo, P., Martins, J. V., Yamasoe, M. A., Procópio, A. S., Pauliquevis, T. M., Andreae, M. O., Guyon, P., Gatti, L. V., and Cordova Leal, A. M.: Physical and chemical properties of aerosols in the wet and dry seasons in Rondônia, Amazonia, J. Geophys. Res., 107, 8081, https://doi.org/10.1029/2001JD000666, 2002.

Artaxo, P., Rizzo, L. V., Brito, J. F., Barbosa, H. M. J., Arana, A., Sena, E. T., Cirino, G. G., Bastos, W., Martin, S. T., and Andreae, M. O.: Atmospheric aerosols in Amazonia and land use change: from natural biogenic to biomass burning conditions, Faraday Discuss., 165, 203-235, https://doi.org/10.1039/c3fd00052d, 2013.

Barbosa, P. M., Stroppiana, D., Grégoire, J.-M., and Cardoso Pereira, J. M.: An assessment of vegetation fire in Africa (1981-1991): Burned areas, burned biomass, and atmospheric emissions, Global Biogeochem. Cy., 13, 933-950, https://doi.org/10.1029/1999GB900042, 1999.

Bilbao, B. A., Leal, A. V., and Méndez, C. L.: Indigenous Use of Fire and Forest Loss in Canaima National Park, Venezuela, Assessment of and Tools for Alternative Strategies of Fire Management in Pemón Indigenous Lands, Hum. Ecol., 38, 663-673, https://doi.org/10.1007/s10745-010-9344-0, 2010.

Bohren, C. F. and Huffman, D. R.: Absorption and scattering of light by small particles, Wiley, Hoboken, NJ, 1983.

Bond, T. C. and Bergstrom, R. W.: Light Absorption by Carbonaceous Particles?: An Investigative Review, Aerosol Sci. Technol., 40, 27-67, https://doi.org/10.1080/02786820500421521, 2006.

Bond, T. C., Streets, D. G., Yarber, K. F., Nelson, S. M., Woo, J.-H., and Klimont, Z.: A technology-based global inventory of black and organic carbon emissions from combustion, J. Geophys. Res., 109, D14203, https://doi.org/10.1029/2003JD003697, 2004.

Bond, T. C., Doherty, S. J., Fahey, D. W., Forster, P. M., Berntsen, T., DeAngelo, B. J., Flanner, M. G., Ghan, S., Kärcher, B., Koch, D., Kinne, S., Kondo, Y., Quinn, P. K., Sarofim, M. C., Schultz, M. G., Schulz, M., Venkataraman, C., Zhang, H., Zhang, S., Bellouin, N., Guttikunda, S. K., Hopke, P. K., Jacobson, M. Z., Kaiser, J. W., Klimont, Z., Lohmann, U., Schwarz, J. P., Shindell, D., Storelvmo, T., Warren, S. G., and Zender, C. S.: Bounding the role of black carbon in the climate system: A scientific assessment, J. Geophys. Res.-Atmos., 118, 5380-5552, https://doi.org/10.1002/jgrd.50171, 2013.
Brito, J., Rizzo, L. V., Morgan, W. T., Coe, H., Johnson, B., Haywood, J., Longo, K., Freitas, S., Andreae, M. O., and Artaxo, P.: Ground-based aerosol characterization during the South American Biomass Burning Analysis (SAMBBA) field experiment, Atmos. Chem. Phys., 14, 12069-12083, https://doi.org/10.5194/acp-14-12069-2014, 2014.

Cachier, H., Bremond, M.-P., and Buat-Ménard, P.: Determination of atmospheric soot carbon with a simple thermal method, Tellus B, 41, 379-390, https://doi.org/10.1111/j.16000889.1989.tb00316.x, 1989.

Caponi, L., Formenti, P., Massabó, D., Di Biagio, C., Cazaunau, M., Pangui, E., Chevaillier, S., Landrot, G., Andreae, M. O., Kandler, K., Piketh, S., Saeed, T., Seibert, D., Williams, E., Balkanski, Y., Prati, P., and Doussin, J.-F.: Spectral- and size-resolved mass absorption efficiency of mineral dust aerosols in the shortwave spectrum: a simulation chamber study, Atmos. Chem. Phys., 17, 7175-7191, https://doi.org/10.5194/acp-17-7175-2017, 2017.

Carbone, S., Brito, J. F., Xu, L., Ng, N. L., Rizzo, L. V., Stern, R., Cirino, G. G., Holanda, B. A., Senna, E., Wolff, S., Saturno, J., Chi, X., Souza, R. A. F., Arana, A., de Sá, M., Pöhlker, M. L., Andreae, M. O., Pöhlker, C., Barbosa, H. M. J., and Artaxo, P.: Long-term chemical composition and source apportionment of submicron aerosol particles in the central Amazon basin (ATTO), Atmos. Chem. Phys. Discuss., in preparation, 2018.

Carslaw, K. S., Lee, L. A., Reddington, C. L., Pringle, K. J., Rap, A., Forster, P. M., Mann, G. W., Spracklen, D. V., Woodhouse, M. T., Regayre, L. A., and Pierce, J. R.: Large contribution of natural aerosols to uncertainty in indirect forcing, Nature, 503, 67-71, https://doi.org/10.1038/nature12674, 2013.

Chand, D., Guyon, P., Artaxo, P., Schmid, O., Frank, G. P., Rizzo, L. V., Mayol-Bracero, O. L., Gatti, L. V., and Andreae, M. O.: Optical and physical properties of aerosols in the boundary layer and free troposphere over the Amazon Basin during the biomass burning season, Atmos. Chem. Phys., 6, 2911-2925, https://doi.org/10.5194/acp-6-2911-2006, 2006.

Chi, X., Winderlich, J., Mayer, J.-C., Panov, A. V., Heimann, M., Birmili, W., Heintzenberg, J., Cheng, Y., and Andreae, M. O.: Long-term measurements of aerosol and carbon monoxide at the ZOTTO tall tower to characterize polluted and pristine air in the Siberian taiga, Atmos. Chem. Phys., 13, 12271-12298, https://doi.org/10.5194/acp-13-12271-2013, 2013.

Chow, J. C., Yu, J. Z., Watson, J. G., Hang Ho, S. S., Bohannan, T. L., Hays, M. D., and Fung, K. K.: The application of thermal methods for determining chemical composition of carbonaceous aerosols: A review, J. Environ. Sci., 42, 1521-1541, https://doi.org/10.1080/10934520701513365, 2007.

Clarke, A. D. and Charlson, R. J.: Radiative Properties of the Background Aerosol: Absorption Component of Extinction, Science, 229, 263-265, https://doi.org/10.1126/science.229.4710.263, 1985.

Cochrane, M. A.: Fire science for rainforests, Nature, 421, 913-919, https://doi.org/10.1038/nature01437, 2003.

Collaud Coen, M., Weingartner, E., Apituley, A., Ceburnis, D., Fierz-Schmidhauser, R., Flentje, H., Henzing, J. S., Jennings, S. G., Moerman, M., Petzold, A., Schmid, O., and Baltensperger, U.: Minimizing light absorption measurement artifacts of the Aethalometer: evaluation of five correction algorithms, Atmos. Meas. Tech., 3, 457-474, https://doi.org/10.5194/amt-3-4572010, 2010. 
Crutzen, P. J. and Andreae, M. O.: Biomass burning in the tropics: Impact on atmospheric chemistry and biogeochemical cycles, Science, 250, 1669-1678, 10.1126/science.250.4988.1669, 1990.

Das, S., Harshvardhan, H., Bian, H., Chin, M., Curci, G., Protonotariou, A. P., Mielonen, T., Zhang, K., Wang, H., and Liu, X.: Biomass burning aerosol transport and vertical distribution over the South African-Atlantic region, J. Geophys. Res.-Atmos., 6391-6415, https://doi.org/10.1002/2016JD026421, 2017.

Davidson, E. A., de Araújo, A. C., Artaxo, P., Balch, J. K., Brown, I. F. C., Bustamante, M. M., Coe, M. T., DeFries, R. S., Keller, M., Longo, M., Munger, J. W., Schroeder, W., Soares-Filho, B. S., Souza, C. M., and Wofsy, S. C.: The Amazon basin in transition, Nature, 481, 321-328, https://doi.org/10.1038/nature10717, 2012.

Denjean, C., Cassola, F., Mazzino, A., Triquet, S., Chevaillier, S., Grand, N., Bourrianne, T., Momboisse, G., Sellegri, K., Schwarzenbock, A., Freney, E., Mallet, M., and Formenti, P.: Size distribution and optical properties of mineral dust aerosols transported in the western Mediterranean, Atmos. Chem. Phys., 16, 1081-1104, https://doi.org/10.5194/acp16-1081-2016, 2016.

Draxler, R. R. and Hess, G. D.: An overview of the HYSPLIT 4 modelling system for trajectories, dispersion and deposition, Aust. Met. Mag., 47, 295-308, 1998.

Drinovec, L., Mocnik, G., Zotter, P., Prévôt, A. S. H., Ruckstuhl, C., Coz, E., Rupakheti, M., Sciare, J., Müller, T., Wiedensohler, A., and Hansen, A. D. A.: The "dual-spot" Aethalometer: an improved measurement of aerosol black carbon with realtime loading compensation, Atmos. Meas. Tech., 8, 1965-1979, https://doi.org/10.5194/amt-8-1965-2015, 2015.

Dubovik, O., Holben, B., Eck, T. F., Smirnov, A., Kaufman, Y. J., King, M. D., Tanré, D., and Slutsker, I.: Variability of Absorption and Optical Properties of Key Aerosol Types Observed in Worldwide Locations, J. Atmos. Sci., 59, 590-608, 2002.

Falster, D. S., Warton, D. I., and Wright, I. J.: SMATR: Standardised major axis tests and routines, ver 2.0, available at: http://www.bio.mq.edu.au/ecology/SMATR/ (last access: 1 June 2017), 2006.

Favez, O., El Haddad, I., Piot, C., Boréave, A., Abidi, E., Marchand, N., Jaffrezo, J.-L., Besombes, J.-L., Personnaz, M.-B., Sciare, J., Wortham, H., George, C., and D'Anna, B.: Intercomparison of source apportionment models for the estimation of wood burning aerosols during wintertime in an Alpine city (Grenoble, France), Atmos. Chem. Phys., 10, 5295-5314, https://doi.org/10.5194/acp-10-5295-2010, 2010.

Fioletov, V. E., McLinden, C. A., Krotkov, N., Li, C., Joiner, J., Theys, N., Carn, S., and Moran, M. D.: A global catalogue of large $\mathrm{SO}_{2}$ sources and emissions derived from the Ozone Monitoring Instrument, Atmos. Chem. Phys., 16, 11497-11519, https://doi.org/10.5194/acp-16-11497-2016, 2016.

Fisch, G., Tota, J., Machado, L. A. T., Silva Dias, M. A. F., da F. Lyra, R. F., Nobre, C. A., Dolman, A. J., and Gash, J. H. C.: The convective boundary layer over pasture and forest in Amazonia, Theor. Appl. Climatol., 78, 47-59, https://doi.org/10.1007/s00704-004-0043-x, 2004.

Formenti, P., Andreae, M. O., Lange, L., Roberts, G., Cafmeyer, J., Rajta, I., Maenhaut, W., Holben, B. N., Artaxo, P., and Lelieveld, J.: Saharan dust in Brazil and Suriname during the
Large-Scale Biosphere-Atmosphere Experiment in Amazonia (LBA) - Cooperative LBA Regional Experiment (CLAIRE) in March 1998, J. Geophys. Res.-Atmos., 106, 14919-14934, https://doi.org/10.1029/2000JD900827, 2001.

Forrister, H., Liu, J., Scheuer, E., Dibb, J., Ziemba, L., Thornhill, K. L., Anderson, B., Diskin, G., Perring, A. E., Schwarz, J. P., Campuzano-Jost, P., Day, D. A., Palm, B. B., Jimenez, J. L., Nenes, A., and Weber, R. J.: Evolution of brown carbon in wildfire plumes, Geophys. Res. Lett., 42, 4623-4630, https://doi.org/10.1002/2015GL063897, 2015.

Fuller, K. A., Malm, W. C., and Kreidenweis, S. M.: Effects of mixing on extinction by carbonaceous particles, J. Geophys. Res.-Atmos., 104, 15941-15954, https://doi.org/10.1029/1998JD100069, 1999.

Fuzzi, S., Decesari, S., Facchini, M. C., Cavalli, F., Emblico, L., Mircea, M., Andreae, M. O., Trebs, I., Hoffer, A., Guyon, P., Artaxo, P., Rizzo, L. V., Lara, L. L., Pauliquevis, T., Maenhaut, W., Raes, N., Chi, X., Mayol-Bracero, O. L., Soto-García, L. L., Claeys, M., Kourtchev, I., Rissler, J., Swietlicki, E., Tagliavini, E., Schkolnik, G., Falkovich, A. H., Rudich, Y., Fisch, G., and Gatti, L. V.: Overview of the inorganic and organic composition of size-segregated aerosol in Rondônia, Brazil, from the biomassburning period to the onset of the wet season, J. Geophys. Res.Atmos., 112, D01201, https://doi.org/10.1029/2005JD006741, 2007.

Garg, S., Chandra, B. P., Sinha, V., Sarda-Esteve, R., Gros, V., and Sinha, B.: Limitation of the Use of the Absorption Angstrom Exponent for Source Apportionment of Equivalent Black Carbon: a Case Study from the North West Indo-Gangetic Plain, Environ. Sci. Technol., 50, 814-824, https://doi.org/10.1021/acs.est.5b03868, 2016.

GES-DISC: Goddard Earth Sciences Data and Information Services Center, available at: https://giovanni.gsfc.nasa.gov/giovanni/, last access: 1 June 2017.

Gläser, G., Wernli, H., Kerkweg, A., and Teubler, F.: The transatlantic dust transport from North Africa to the Americas-Its characteristics and source regions, J. Geophys. Res.-Atmos., 120, 11231-11252, https://doi.org/10.1002/2015JD023792, 2015.

Guyon, P., Graham, B., Beck, J., Boucher, O., Gerasopoulos, E., Mayol-Bracero, O. L., Roberts, G. C., Artaxo, P., and Andreae, M. O.: Physical properties and concentration of aerosol particles over the Amazon tropical forest during background and biomass burning conditions, Atmos. Chem. Phys., 3, 951-967, https://doi.org/10.5194/acp-3-951-2003, 2003a.

Guyon, P., Boucher, O., Graham, B., Beck, J., Mayol-Bracero, O. L., Roberts, G. C., Maenhaut, W., Artaxo, P., and Andreae, M. O.: Refractive index of aerosol particles over the Amazon tropical forest during LBA-EUSTACH 1999, J. Aerosol Sci., 34, 883907, https://doi.org/10.1016/S0021-8502(03)00052-1, 2003b.

Guyon, P., Graham, B., Roberts, G. C., Mayol-Bracero, O. L., Maenhaut, W., Artaxo, P., and Andreae, M. O.: Sources of optically active aerosol particles over the Amazon forest, Atmos. Environ., 38, 1039-1051, https://doi.org/10.1016/j.atmosenv.2003.10.051, 2004.

Guyon, P., Frank, G. P., Welling, M., Chand, D., Artaxo, P., Rizzo, L., Nishioka, G., Kolle, O., Fritsch, H., Silva Dias, M. A. F., Gatti, L. V., Cordova, A. M., and Andreae, M. O.: Airborne measurements of trace gas and aerosol particle emissions from 
biomass burning in Amazonia, Atmos. Chem. Phys., 5, 29893002, https://doi.org/10.5194/acp-5-2989-2005, 2005.

Gysel, M., Laborde, M., Olfert, J. S., Subramanian, R., and Gröhn, A. J.: Effective density of Aquadag and fullerene soot black carbon reference materials used for SP2 calibration, Atmos. Meas. Tech., 4, 2851-2858, https://doi.org/10.5194/amt-4-2851-2011, 2011.

Hamilton, D. S., Lee, L. A., Pringle, K. J., Reddington, C. L., Spracklen, D. V., and Carslaw, K. S.: Occurrence of pristine aerosol environments on a polluted planet, P. Natl. Acad. Sci. USA, 111, 18466-18471, https://doi.org/10.1073/pnas.1415440111, 2014.

Hansen, A. D. A., Rosen, H., and Novakov, T.: The aethalometer - An instrument for the real-time measurement of optical absorption by aerosol particles, Sci. Total Environ., 36, 191-196, https://doi.org/10.1016/0048-9697(84)90265-1, 1984.

Hoffer, A., Gelencsér, A., Guyon, P., Kiss, G., Schmid, O., Frank, G. P., Artaxo, P., and Andreae, M. O.: Optical properties of humiclike substances (HULIS) in biomass-burning aerosols, Atmos. Chem. Phys., 6, 3563-3570, https://doi.org/10.5194/acp-6-35632006, 2006.

IPCC: Climate Change 2013: The Physical Science Basis, Contribution of Working Group I to the Fifth Assessment Report of the Intergovernmental Panel on Climate Change, edited by: Stocker, T. F., Qin, D., Plattner, G.-K., Tignor, M., Allen, S. K., Boschung, J., Nauels, A., Xia, Y., Bex, V., and Midgley, P. M., Cambridge University Press, Cambridge, UK, New York, NY, USA, 1535 pp., 2013.

Janhäll, S., Andreae, M. O., and Pöschl, U.: Biomass burning aerosol emissions from vegetation fires: particle number and mass emission factors and size distributions, Atmos. Chem. Phys., 10, 1427-1439, https://doi.org/10.5194/acp-101427-2010, 2010.

Kirchstetter, T. W., Novakov, T., and Hobbs, P. V.: Evidence that the spectral dependence of light absorption by aerosols is affected by organic carbon, J. Geophys. Res.-Atmos., 109, D21208, https://doi.org/10.1029/2004JD004999, 2004.

Kondo, Y., Matsui, H., Moteki, N., Sahu, L., Takegawa, N., Kajino, M., Zhao, Y., Cubison, M. J., Jimenez, J. L., Vay, S., Diskin, G. S., Anderson, B., Wisthaler, A., Mikoviny, T., Fuelberg, H. E., Blake, D. R., Huey, G., Weinheimer, A. J., Knapp, D. J., and Brune, W. H.: Emissions of black carbon, organic, and inorganic aerosols from biomass burning in North America and Asia in 2008, J. Geophys. Res., 116, D08204, https://doi.org/10.1029/2010JD015152, 2011.

Laborde, M., Crippa, M., Tritscher, T., Jurányi, Z., Decarlo, P. F., Temime-Roussel, B., Marchand, N., Eckhardt, S., Stohl, A., Baltensperger, U., Prévôt, A. S. H., Weingartner, E., and Gysel, M.: Black carbon physical properties and mixing state in the European megacity Paris, Atmos. Chem. Phys., 13, 5831-5856, https://doi.org/10.5194/acp-13-5831-2013, 2013.

Lack, D. A. and Langridge, J. M.: On the attribution of black and brown carbon light absorption using the Ångström exponent, Atmos. Chem. Phys., 13, 10535-10543, https://doi.org/10.5194/acp-13-10535-2013, 2013.

Lack, D. A., Cappa, C. D., Covert, D. S., Baynard, T., Massoli, P., Sierau, B., Bates, T. S., Quinn, P. K., Lovejoy, E. R., and Ravishankara, A. R.: Bias in Filter-Based Aerosol Light Absorption Measurements Due to Organic Aerosol Loading: Evidence from
Ambient Measurements, Aerosol Sci. Technol., 42, 1033-1041, https://doi.org/10.1080/02786820802389277, 2008.

Lack, D. A., Bahreini, R., Langridge, J. M., Gilman, J. B., and Middlebrook, A. M.: Brown carbon absorption linked to organic mass tracers in biomass burning particles, Atmos. Chem. Phys., 13, 2415-2422, https://doi.org/10.5194/acp-132415-2013, 2013.

Laskin, A., Laskin, J., and Nizkorodov, S. A.: Chemistry of Atmospheric Brown Carbon, Chem. Rev., 115, 4335-4382, https://doi.org/10.1021/cr5006167, 2015.

Lewis, K., Arnott, W. P., Moosmüller, H., and Wold, C. E.: Strong spectral variation of biomass smoke light absorption and single scattering albedo observed with a novel dual-wavelength photoacoustic instrument, J. Geophys. Res., 113, D16203, https://doi.org/10.1029/2007JD009699, 2008.

Lewis, S. L., Brando, P. M., Phillips, O. L., van der Heijden, G. M. F., and Nepstad, D.: The 2010 Amazon Drought, Science, 331, 554-554, https://doi.org/10.1126/science.1200807, 2011.

Liu, D., Flynn, M., Gysel, M., Targino, A., Crawford, I., Bower, K., Choularton, T., Jurányi, Z., Steinbacher, M., Hüglin, C., Curtius, J., Kampus, M., Petzold, A., Weingartner, E., Baltensperger, U., and Coe, H.: Single particle characterization of black carbon aerosols at a tropospheric alpine site in Switzerland, Atmos. Chem. Phys., 10, 7389-7407, https://doi.org/10.5194/acp10-7389-2010, 2010.

Liu, D., Taylor, J. W., Young, D. E., Flynn, M. J., Coe, H., and Allan, J. D.: The effect of complex black carbon microphysics on the determination of the optical properties of brown carbon, Geophys. Res. Lett., 42, 613-619, https://doi.org/10.1002/2014GL062443, 2015.

Liu, D., Whitehead, J., Alfarra, M. R., Reyes-Villegas, E., Spracklen, D. V., Reddington, C. L., Kong, S., Williams, P. I., Ting, Y.-C., Haslett, S., Taylor, J. W., Flynn, M. J., Morgan, W. T., McFiggans, G., Coe, H., and Allan, J. D.: Black-carbon absorption enhancement in the atmosphere determined by particle mixing state, Nat. Geosci., 10, 184-188, https://doi.org/10.1038/ngeo2901, 2017.

Martin, S. T., Andreae, M. O., Althausen, D., Artaxo, P., Baars, H., Borrmann, S., Chen, Q., Farmer, D. K., Guenther, A., Gunthe, S. S., Jimenez, J. L., Karl, T., Longo, K., Manzi, A., Müller, T., Pauliquevis, T., Petters, M. D., Prenni, A. J., Pöschl, U., Rizzo, L. V., Schneider, J., Smith, J. N., Swietlicki, E., Tota, J., Wang, J., Wiedensohler, A., and Zorn, S. R.: An overview of the Amazonian Aerosol Characterization Experiment 2008 (AMAZE-08), Atmos. Chem. Phys., 10, 1141511438, https://doi.org/10.5194/acp-10-11415-2010, 2010a.

Martin, S. T., Andreae, M. O., Artaxo, P., Baumgardner, D., Chen, Q., Goldstein, A. H., Guenther, A., Heald, C. L., Mayol-Bracero, O. L., McMurry, P. H., Pauliquevis, T., Pöschl, U., Prather, K. A., Roberts, G. C., Saleska, S. R., Silva Dias, M. A., Spracklen, D. V., Swietlicki, E., and Trebs, I.: Sources and properties of Amazonian aerosol particles, Rev. Geophys., 48, RG2002, https://doi.org/10.1029/2008RG000280, 2010b.

Martin, S. T., Artaxo, P., Machado, L. A. T., Manzi, A. O., Souza, R. A. F., Schumacher, C., Wang, J., Andreae, M. O., Barbosa, H. M. J., Fan, J., Fisch, G., Goldstein, A. H., Guenther, A., Jimenez, J. L., Pöschl, U., Silva Dias, M. A., Smith, J. N., and Wendisch, M.: Introduction: Observations and Modeling of the Green Ocean 
Amazon (GoAmazon2014/5), Atmos. Chem. Phys., 16, 47854797, https://doi.org/10.5194/acp-16-4785-2016, 2016.

Martin, S. T., Artaxo, P., Machado, L., Manzi, A. O., Souza, R. A. F., Schumacher, C., Wang, J., Biscaro, T., Brito, J., Calheiros, A., Jardine, K., Medeiros, A., Portela, B., de Sá, S. S., Adachi, K., Aiken, A. C., Albrecht, R., Alexander, L., Andreae, M. O., Barbosa, H. M. J., Buseck, P., Chand, D., Comstock, J. M., Day, D. A., Dubey, M., Fan, J., Fast, J., Fisch, G., Fortner, E., Giangrande, S., Gilles, M., Goldstein, A. H., Guenther, A., Hubbe, J., Jensen, M., Jimenez, J. L., Keutsch, F. N., Kim, S., Kuang, C., Laskin, A., McKinney, K., Mei, F., Miller, M., Nascimento, R., Pauliquevis, T., Pekour, M., Peres, J., Petäjä, T., Pöhlker, C., Pöschl, U., Rizzo, L., Schmid, B., Shilling, J. E., Dias, M. A. S., Smith, J. N., Tomlinson, J. M., Tóta, J., and Wendisch, M.: The Green Ocean Amazon Experiment (GoAmazon2014/5) Observes Pollution Affecting Gases, Aerosols, Clouds, and Rainfall over the Rain Forest, B. Am. Meteorol. Soc., 98, 981-997, https://doi.org/10.1175/BAMS-D-15-00221.1, 2017.

Massabò, D., Caponi, L., Bernardoni, V., Bove, M. C., Brotto, P., Calzolai, G., Cassola, F., Chiari, M., Fedi, M. E., Fermo, P., Giannoni, M., Lucarelli, F., Nava, S., Piazzalunga, A., Valli, G. Vecchi, R., and Prati, P.: Multi-wavelength optical determination of black and brown carbon in atmospheric aerosols, Atmos. Environ., 108, 1-12, https://doi.org/10.1016/j.atmosenv.2015.02.058, 2015.

Mikhailov, E. F., Mironova, S., Mironov, G., Vlasenko, S., Panov, A., Chi, X., Walter, D., Carbone, S., Artaxo, P., Heimann, M., Lavric, J., Pöschl, U., and Andreae, M. O.: Long-term measurements (2010-2014) of carbonaceous aerosol and carbon monoxide at the Zotino Tall Tower Observatory (ZOTTO) in central Siberia, Atmos. Chem. Phys., 17, 14365-14392, https://doi.org/10.5194/acp-17-14365-2017, 2017.

Mishchenko, M. I., Dlugach, J. M., Yanovitskij, E. G., and Zakharova, N. T.: Bidirectional reflectance of flat, optically thick particulate layers: an efficient radiative transfer solution and applications to snow and soil surfaces, J. Quant. Spectrosc. Ra., 63, 409-432, https://doi.org/10.1016/S0022-4073(99)00028-X, 1999.

Moosmüller, H., Chakrabarty, R. K., Ehlers, K. M., and Arnott, W. P.: Absorption Ångström coefficient, brown carbon, and aerosols: basic concepts, bulk matter, and spherical particles, Atmos. Chem. Phys., 11, 1217-1225, https://doi.org/10.5194/acp11-1217-2011, 2011.

Moran-Zuloaga, D., Ditas, F., Walter, D., Saturno, J., Brito, J., Carbone, S., Chi, X., Hrabe de Angelis, I., Baars, H., Godoi, R. H. M., Heese, B., Holanda, B. A., Lavric, J. V., Martin, S. T., Ming, J., Pöhlker, M. L., Ruckteschler, N., Su, H., Wang, Y., Wang, Q., Wang, Z., Weber, B., Wolff, S., Artaxo, P., Pöschl, U., Andreae, M. O., and Pöhlker, C.: Long-term study on coarse mode aerosols in the Amazon rain forest with the frequent intrusion of Saharan dust plumes, Atmos. Chem. Phys., 18, 10055-10088, https://doi.org/10.5194/acp-18-10055-2018, 2018.

Moteki, N. and Kondo, Y.: Method to measure timedependent scattering cross sections of particles evaporating in a laser beam, J. Aerosol Sci., 39, 348-364, https://doi.org/10.1016/j.jaerosci.2007.12.002, 2008

Müller, T., Henzing, J. S., de Leeuw, G., Wiedensohler, A., Alastuey, A., Angelov, H., Bizjak, M., Collaud Coen, M., Engström, J. E., Gruening, C., Hillamo, R., Hoffer, A., Imre, K.,
Ivanow, P., Jennings, G., Sun, J. Y., Kalivitis, N., Karlsson, H., Komppula, M., Laj, P., Li, S.-M., Lunder, C., Marinoni, A., Martins dos Santos, S., Moerman, M., Nowak, A., Ogren, J. A., Petzold, A., Pichon, J. M., Rodriquez, S., Sharma, S., Sheridan, P. J., Teinilä, K., Tuch, T., Viana, M., Virkkula, A., Weingartner, E., Wilhelm, R., and Wang, Y. Q.: Characterization and intercomparison of aerosol absorption photometers: result of two intercomparison workshops, Atmos. Meas. Tech., 4, 245-268, https://doi.org/10.5194/amt-4-245-2011, 2011a.

Müller, T., Laborde, M., Kassell, G., and Wiedensohler, A.: Design and performance of a three-wavelength LED-based total scatter and backscatter integrating nephelometer, Atmos. Meas. Tech., 4, 1291-1303, https://doi.org/10.5194/amt-4-1291-2011, $2011 \mathrm{~b}$.

Nepstad, D. C., Stickler, C. M., Filho, B. S., and Merry, F.: Interactions among Amazon land use, forests and climate: prospects for a near-term forest tipping point, Philos. T. Roy. Soc. B, 363, 1737-1746, https://doi.org/10.1098/rstb.2007.0036, 2008.

Ng, N. L., Herndon, S. C., Trimborn, A., Canagaratna, M. R., Croteau, P. L., Onasch, T. B., Sueper, D., Worsnop, D. R., Zhang, Q., Sun, Y. L., and Jayne, J. T.: An Aerosol Chemical Speciation Monitor (ACSM) for Routine Monitoring of the Composition and Mass Concentrations of Ambient Aerosol, Aerosol Sci. Technol., 45, 780-794, https://doi.org/10.1080/02786826.2011.560211, 2011.

Petzold, A. and Schönlinner, M.: Multi-angle absorption photometry - a new method for the measurement of aerosol light absorption and atmospheric black carbon, J. Aerosol Sci., 35, 421-441, https://doi.org/10.1016/j.jaerosci.2003.09.005, 2004.

Petzold, A., Ogren, J. A., Fiebig, M., Laj, P., Li, S.-M., Baltensperger, U., Holzer-Popp, T., Kinne, S., Pappalardo, G., Sugimoto, N., Wehrli, C., Wiedensohler, A., and Zhang, X.-Y.: Recommendations for reporting "black carbon" measurements, Atmos. Chem. Phys., 13, 8365-8379, https://doi.org/10.5194/acp13-8365-2013, 2013.

Pöhlker, C., Saturno, J., Krüger, M. L., Förster, J.-D., Weigand, M., Wiedemann, K. T., Bechtel, M., Artaxo, P., and Andreae, M. O.: Efflorescence upon humidification? X-ray microspectroscopic in-situ observation of changes in aerosol microstructure and phase state upon hydration, Geophys. Res. Lett., 41, 36813689, https://doi.org/10.1002/2014GL059409, 2014.

Pöhlker, C., Walter, D., Paulsen, H., Könemann, T., RodríguezCaballero, E., Moran-Zuloaga, D., Brito, J., Carbone, S., Degrendele, C., Després, V. R., Ditas, F., Holanda, B. A., Kaiser, J. W., Lammel, G., Lavric, J. V., Ming, J., Pickersgill, D., Pöhlker, M. L., Praß, M., Ruckteschler, N., Saturno, J., Sörgel, M., Wang, Q., Weber, B., Wolff, S., Artaxo, P., Pöschl, U., and Andreae, M. O.: Land cover and its transformation in the backward trajectory footprint region of the Amazon Tall Tower Observatory, Atmos. Chem. Phys. Discuss., https://doi.org/10.5194/acp-2018-323, in review, 2018.

Pöhlker, M. L., Ditas, F., Saturno, J., Klimach, T., Hrabe de Angelis, I., Araùjo, A. C., Brito, J., Carbone, S., Cheng, Y., Chi, X., Ditz, R., Gunthe, S. S., Holanda, B. A., Kandler, K., Kesselmeier, J., Könemann, T., Krüger, O. O., Lavric, J. V., Martin, S. T., Mikhailov, E., Moran-Zuloaga, D., Rizzo, L. V., Rose, D., Su, H., Thalman, R., Walter, D., Wang, J., Wolff, S., Barbosa, H. M. J., Artaxo, P., Andreae, M. O., Pöschl, U., and Pöhlker, C.: Long-term observations of cloud condensation nuclei over the Amazon rain forest - Part 2: Variability and charac- 
teristics of biomass burning, long-range transport, and pristine rain forest aerosols, Atmos. Chem. Phys., 18, 10289-10331, https://doi.org/10.5194/acp-18-10289-2018, 2018.

Pokhrel, R. P., Wagner, N. L., Langridge, J. M., Lack, D. A., Jayarathne, T., Stone, E. A., Stockwell, C. E., Yokelson, R. J., and Murphy, S. M.: Parameterization of single-scattering albedo (SSA) and absorption Ångström exponent (AAE) with EC / OC for aerosol emissions from biomass burning, Atmos. Chem. Phys., 16, 9549-9561, https://doi.org/10.5194/acp-169549-2016, 2016.

Pöschl, U., Martin, S. T., Sinha, B., Chen, Q., Gunthe, S. S., Huffman, J. A., Borrmann, S., Farmer, D. K., Garland, R. M., Helas, G., Jimenez, J. L., King, S. M., Manzi, A., Mikhailov, E., Pauliquevis, T., Petters, M. D., Prenni, A. J., Roldin, P., Rose, D., Schneider, J., Su, H., Zorn, S. R., Artaxo, P., and Andreae, M. O.: Rainforest Aerosols as Biogenic Nuclei of Clouds and Precipitation in the Amazon, Science, 329, 15131516, https://doi.org/10.1126/science.1191056, 2010.

Prospero, J. M., Glaccum, R. A., and Nees, R. T.: Atmospheric transport of soil dust from Africa to South America, Nature, 289, 570-572, https://doi.org/10.1038/289570a0, 1981.

Raatikainen, T., Brus, D., Hyvärinen, A.-P., Svensson, J., Asmi, E., and Lihavainen, H.: Black carbon concentrations and mixing state in the Finnish Arctic, Atmos. Chem. Phys., 15, 1005710070, https://doi.org/10.5194/acp-15-10057-2015, 2015.

R Development Core Team: R: A language and environment for statistical computing, available at: http://www.r-project.org (last access: 1 June 2017), 2009.

Reid, J. S., Hobbs, P. V, Ferek, R. J., Blake, D. R., Martins, J. V., Dunlap, M. R., and Liousse, C.: Physical, chemical, and optical properties of regional hazes dominated by smoke in Brazil, J. Geophys. Res.-Atmos., 103, 32059-32080, https://doi.org/10.1029/98JD00458, 1998.

Reid, J. S., Eck, T. F., Christopher, S. A., Koppmann, R., Dubovik, O., Eleuterio, D. P., Holben, B. N., Reid, E. A., and Zhang, J.: A review of biomass burning emissions part III: intensive optical properties of biomass burning particles, Atmos. Chem. Phys., 5, 827-849, https://doi.org/10.5194/acp-5-827-2005, 2005.

Ridley, D. A., Heald, C. L., and Prospero, J. M.: What controls the recent changes in African mineral dust aerosol across the Atlantic?, Atmos. Chem. Phys., 14, 5735-5747, https://doi.org/10.5194/acp-14-5735-2014, 2014.

Rincón, A. G., Guzmán, M. I., Hoffmann, M. R., and Colussi, A. J.: Thermochromism of Model Organic Aerosol Matter, J. Phys. Chem. Lett., 1, 368-373, https://doi.org/10.1021/jz900186e, 2010.

Rizzo, L. V., Correia, A. L., Artaxo, P., Procópio, A. S., and Andreae, M. O.: Spectral dependence of aerosol light absorption over the Amazon Basin, Atmos. Chem. Phys., 11, 8899-8912, https://doi.org/10.5194/acp-11-8899-2011, 2011.

Rizzo, L. V., Artaxo, P., Müller, T., Wiedensohler, A., Paixão, M., Cirino, G. G., Arana, A., Swietlicki, E., Roldin, P., Fors, E. O., Wiedemann, K. T., Leal, L. S. M., and Kulmala, M.: Long term measurements of aerosol optical properties at a primary forest site in Amazonia, Atmos. Chem. Phys., 13, 2391-2413, https://doi.org/10.5194/acp-13-2391-2013, 2013.

Roberts, G. C., Nenes, A., Seinfeld, J. H., and Andreae, M. O.: Impact of biomass burning on cloud proper- ties in the Amazon Basin, J. Geophys. Res., 108, 4062, https://doi.org/10.1029/2001JD000985, 2003.

Saleh, R., Hennigan, C. J., McMeeking, G. R., Chuang, W. K., Robinson, E. S., Coe, H., Donahue, N. M., and Robinson, A. L.: Absorptivity of brown carbon in fresh and photo-chemically aged biomass-burning emissions, Atmos. Chem. Phys., 13, 76837693, https://doi.org/10.5194/acp-13-7683-2013, 2013.

Saleh, R., Robinson, E. S., Tkacik, D. S., Ahern, A. T., Liu, S., Aiken, A. C., Sullivan, R. C., Presto, A. A., Dubey, M. K., Yokelson, R. J., Donahue, N. M., and Robinson, A. L.: Brownness of organics in aerosols from biomass burning linked to their black carbon content, Nat. Geosci., 7, 2-5, https://doi.org/10.1038/ngeo2220, 2014.

Salvador, P., Almeida, S. M., Cardoso, J., Almeida-Silva, M., Nunes, T., Cerqueira, M., Alves, C., Reis, M. A., Chaves, P. C., Artíñano, B., and Pio, C.: Composition and origin of $\mathrm{PM}_{10}$ in Cape Verde: Characterization of longrange transport episodes, Atmos. Environ., 127, 326-339, https://doi.org/10.1016/j.atmosenv.2015.12.057, 2016.

Sandradewi, J., Prévôt, A. S. H., Szidat, S., Perron, N., Alfarra, M. R., Lanz, V. A., Weingartner, E., and Baltensperger, U.: Using aerosol light absorption measurements for the quantitative determination of wood burning and traffic emission contributions to particulate matter, Environ. Sci. Technol., 42, 3316-3323, https://doi.org/10.1021/es702253m, 2008.

Saturno, J., Pöhlker, C., Massabò, D., Brito, J., Carbone, S., Cheng, Y., Chi, X., Ditas, F., Hrabe de Angelis, I., Morán-Zuloaga, D., Pöhlker, M. L., Rizzo, L. V., Walter, D., Wang, Q., Artaxo, P., Prati, P., and Andreae, M. O.: Comparison of different Aethalometer correction schemes and a reference multiwavelength absorption technique for ambient aerosol data, Atmos. Meas. Tech., 10, 2837-2850, https://doi.org/10.5194/amt10-2837-2017, 2017.

Saturno, J., Ditas, F., Penning de Vries, M., Holanda, B. A., Pöhlker, M. L., Carbone, S., Walter, D., Bobrowski, N., Brito, J., Chi, X., Gutmann, A., Hrabe de Angelis, I., Machado, L. A. T., Moran-Zuloaga, D., Rüdiger, J., Schneider, J., Schulz, C., Wang, Q., Wendisch, M., Artaxo, P., Wagner, T., Pöschl, U., Andreae, M. O., and Pöhlker, C.: African volcanic emissions influencing atmospheric aerosols over the Amazon rain forest, Atmos. Chem. Phys., 18, 10391-10405, https://doi.org/10.5194/acp-18-103912018, 2018a.

Saturno, J., Holanda, B., Pöhlker, C., Ditas, F., Wang, Q., MoranZuloaga, D., Brito, J., Carbone, S., Cheng, Y., Chi, X., Ditas, J., Hoffmann, T., Hrabe de Angelis, I., Könemann, T., Lavric, J., Ma, N., Ming, J., Paulsen, H., Pöhlker, M., Rizzo, L., Schlag, P., Su, H., Walter, D., Wolff, S., Zhang, Y., Artaxo, P., Pöschl, U., and Andreae, M. O.: Available data for ATTO BC and BrC study, Max Planck Society, https://doi.org/10.17617/3.1r, 2018b.

Schkolnik, G., Chand, D., Hoffer, A., Andreae, M. O., Erlick, C., Swietlicki, E., and Rudich, Y.: Constraining the density and complex refractive index of elemental and organic carbon in biomass burning aerosol using optical and chemical measurements, Atmos. Environ., 41, 1107-1118, https://doi.org/10.1016/j.atmosenv.2006.09.035, 2007.

Schuster, G. L., Dubovik, O., Arola, A., Eck, T. F., and Holben, B. N.: Remote sensing of soot carbon - Part 2: Understanding the absorption Ångström exponent, Atmos. Chem. Phys., 16, 15871602, https://doi.org/10.5194/acp-16-1587-2016, 2016. 
Schwarz, J. P., Gao, R. S., Fahey, D. W., Thomson, D. S., Watts, L. A., Wilson, J. C., Reeves, J. M., Darbeheshti, M., Baumgardner, D. G., Kok, G. L., Chung, S. H., Schulz, M., Hendricks, J., Lauer, A., Kärcher, B., Slowik, J. G., Rosenlof, K. H., Thompson, T. L., Langford, A. O., Loewenstein, M., and Aikin, K. C.: Single-particle measurements of midlatitude black carbon and light-scattering aerosols from the boundary layer to the lower stratosphere, J. Geophys. Res., 111, D16207, https://doi.org/10.1029/2006JD007076, 2006.

Seinfeld, J. H., Bretherton, C., Carslaw, K. S., Coe, H., DeMott, P. J., Dunlea, E. J., Feingold, G., Ghan, S., Guenther, A. B., Kahn, R., Kraucunas, I., Kreidenweis, S. M., Molina, M. J., Nenes, A., Penner, J. E., Prather, K. A., Ramanathan, V., Ramaswamy, V., Rasch, P. J., Ravishankara, A. R., Rosenfeld, D., Stephens, G., and Wood, R.: Improving our fundamental understanding of the role of aerosol-cloud interactions in the climate system, P. Natl. Acad. Sci. USA, 113, 5781-5790, https://doi.org/10.1073/pnas.1514043113, 2016.

Snelling, D. R., Smallwood, G. J., Liu, F., Gülder, Ö. L., and Bachalo, W. D.: A calibration-independent laserinduced incandescence technique for soot measurement by detecting absolute light intensity, Appl. Opt., 44, 6773, https://doi.org/10.1364/AO.44.006773, 2005.

Stephens, M., Turner, N., and Sandberg, J.: Particle Identification by Laser-Induced Incandescence in a Solid-State Laser Cavity, Appl. Opt., 42, 3726, https://doi.org/10.1364/AO.42.003726, 2003

Stull, R. B.: An Introduction to Boundary Layer Meteorology, Springer, the Netherlands, 1988.

Subramanian, R., Kok, G. L., Baumgardner, D., Clarke, A., Shinozuka, Y., Campos, T. L., Heizer, C. G., Stephens, B. B., de Foy, B., Voss, P. B., and Zaveri, R. A.: Black carbon over Mexico: the effect of atmospheric transport on mixing state, mass absorption cross-section, and BC / CO ratios, Atmos. Chem. Phys., 10, 219-237, https://doi.org/10.5194/acp-10-219-2010, 2010.

Sumlin, B. J., Pandey, A., Walker, M. J., Pattison, R. S., Williams, B. J., and Chakrabarty, R. K.: Atmospheric Photooxidation Diminishes Light Absorption by Primary Brown Carbon Aerosol from Biomass Burning, Environ. Sci. Technol. Lett., 4, 540-545, https://doi.org/10.1021/acs.estlett.7b00393, 2017.

Talbot, R. W., Andreae, M. O., Berresheim, H., Artaxo, P., Garstang, M., Harriss, R. C., Beecher, K. M., and Li, S. M.: Aerosol chemistry during the wet season in central Amazonia: The influence of long-range transport, J. Geophys. Res., 95, 16955, https://doi.org/10.1029/JD095iD10p16955, 1990.

Tasoglou, A., Saliba, G., Subramanian, R., and Pandis, S. N.: Absorption of chemically aged biomass burning carbonaceous aerosol, J. Aerosol Sci., 113, 141-152, https://doi.org/10.1016/j.jaerosci.2017.07.011, 2017.

Tuch, T. M., Haudek, A., Müller, T., Nowak, A., Wex, H., and Wiedensohler, A.: Design and performance of an automatic regenerating adsorption aerosol dryer for continuous operation at monitoring sites, Atmos. Meas. Tech., 2, 417-422, https://doi.org/10.5194/amt-2-417-2009, 2009.

Virkkula, A., Backman, J., Aalto, P. P., Hulkkonen, M., Riuttanen, L., Nieminen, T., dal Maso, M., Sogacheva, L., de Leeuw, G., and Kulmala, M.: Seasonal cycle, size dependencies, and source analyses of aerosol optical properties at the SMEAR II mea- surement station in Hyytiälä, Finland, Atmos. Chem. Phys., 11, 4445-4468, https://doi.org/10.5194/acp-11-4445-2011, 2011.

Wang, Q., Huang, R.-J., Cao, J., Han, Y., Wang, G., Li, G., Wang, Y., Dai, W., Zhang, R., and Zhou, Y.: Mixing State of Black Carbon Aerosol in a Heavily Polluted Urban Area of China: Implications for Light Absorption Enhancement, Aerosol Sci. Technol., 48, 689-697, https://doi.org/10.1080/02786826.2014.917758, 2014.

Wang, Q., Saturno, J., Chi, X., Walter, D., Lavric, J. V., Moran-Zuloaga, D., Ditas, F., Pöhlker, C., Brito, J., Carbone, S., Artaxo, P., and Andreae, M. O.: Modeling investigation of light-absorbing aerosols in the Amazon Basin during the wet season, Atmos. Chem. Phys., 16, 14775-14794, https://doi.org/10.5194/acp-16-14775-2016, 2016 a.

Wang, X., Heald, C. L., Sedlacek, A. J., de Sá, S. S., Martin, S. T., Alexander, M. L., Watson, T. B., Aiken, A. C., Springston, S. R., and Artaxo, P.: Deriving brown carbon from multiwavelength absorption measurements: method and application to AERONET and Aethalometer observations, Atmos. Chem. Phys., 16, 12733 12752, https://doi.org/10.5194/acp-16-12733-2016, 2016b.

Warton, D. I., Wright, I. J., Falster, D. S., and Westoby, M.: Bivariate line-fitting methods for allometry, Biol. Rev. Camb. Philos. Soc., 81, 259-291, https://doi.org/10.1017/S1464793106007007, 2006.

Weingartner, E., Saathoff, H., Schnaiter, M., Streit, N., Bitnar, B., and Baltensperger, U.: Absorption of light by soot particles: determination of the absorption coefficient by means of aethalometers, J. Aerosol Sci., 34, 1445-1463, https://doi.org/10.1016/S0021-8502(03)00359-8, 2003.

Winderlich, J., Chen, H., Gerbig, C., Seifert, T., Kolle, O., Lavric, J. V., Kaiser, C., Höfer, A., and Heimann, M.: Continuous lowmaintenance $\mathrm{CO}_{2} / \mathrm{CH}_{4} / \mathrm{H}_{2} \mathrm{O}$ measurements at the Zotino Tall Tower Observatory (ZOTTO) in Central Siberia, Atmos. Meas. Tech., 3, 1113-1128, https://doi.org/10.5194/amt-3-1113-2010, 2010.

Womack, C., Manfred, K., Wagner, N., He, Q., Rudich, Y., Brown, S., and Washenfelder, R.: Characterizing the optical properties of brown carbon aerosol from biomass burning using broadband cavity enhanced spectroscopy, in Atmospheric Chemistry Gordon Research Conference, 2017.

Wong, J. P. S., Nenes, A., and Weber, R. J.: Changes in Light Absorptivity of Molecular Weight Separated Brown Carbon Due to Photolytic Aging, Environ. Sci. Technol., 51, 8414-8421, https://doi.org/10.1021/acs.est.7b01739, 2017.

Zanatta, M., Gysel, M., Bukowiecki, N., Müller, T., Weingartner, E., Areskoug, H., Fiebig, M., Yttri, K. E., Mihalopoulos, N., Kouvarakis, G., Beddows, D., Harrison, R. M., Cavalli, F., Putaud, J. P., Spindler, G., Wiedensohler, A., Alastuey, A., Pandolfi, M., Sellegri, K., Swietlicki, E., Jaffrezo, J. L., Baltensperger, U., and Laj, P.: A European aerosol phenomenology-5: Climatology of black carbon optical properties at 9 regional background sites across Europe, Atmos. Environ., 145, 346-364, https://doi.org/10.1016/j.atmosenv.2016.09.035, 2016. 